\title{
Prevalence and management of Solenopsis invicta in China
}

\author{
Lei Wang', Ling Zeng', Yijuan Xu', Yongyue Lu' \\ I Red Imported Fire Ant Research Centre, South China Agricultural University, 483 Wushan Road, Guangzhou, \\ Guangdong 510642, China
}

Corresponding author: Yongyue Lu (luyongyue@scau.edu.cn)

Academic editor: Jianghua Sun | Received 26 July 2019 | Accepted 13 January 2020 | Published 20 March 2020

Citation: Wang L, Zeng L, Xu Y, L Y (2020) Prevalence and management of Solenopsis invicta in China. NeoBiota 54: 89-124. https://doi.org/10.3897/neobiota.54.38584

\begin{abstract}
Red imported fire ant, Solenopsis invicta, was first found in Taiwan province of China in 2003. To prevent transboundary expansion, the Chinese government has formulated various control strategies in the last 15 years to slow down the spread of $S$. invicta. Despite all efforts, $S$. invicta invasion has reached more than 390 counties of 13 provinces and two special administrative regions in China; at present, S. invicta remains at the stage of rapid expansion. The transnational entry of $S$. invicta is linked to imported logs and wastepaper coming mostly from the United States. In domestic settings, long-distance expansion of $S$. invicta relied on potted plant and turf transportation. Both monogyne and polygyne social forms of $S$. invicta were present in China with polygyne colonies as the dominant one. Data on population and breeding dynamics of $S$. invicta reveal the presence of two peaks annually with nuptial flights occurring throughout the year. Arthropods, plant seeds, and honeydew are important food sources of S. invicta, thereby causing negative impacts on the abundance, diversity, and richness of native arthropod communities. Fire ants are threats not only to agriculture and power facilities, but also to human health, with more than $30 \%$ of people having suffered from the sting and $10 \%$ having experienced an allergic reaction. To address the expansion of S. invicta, the National Fire Ant Detection and Management Union was established and the formulation and implementation of management policies were drawn. Plant quarantine becomes an essential step in fire ant management, whereas the two-step method of combing toxic baits and contact dust emerges as the forefront method crucial in managing S. invicta. The experience and lessons learned from fire ant management in China could benefit other countries when facing similar challenges.
\end{abstract}

\section{Keywords}

Control, fire ant, invasive ant, management policies, quarantine 


\section{Introduction}

China suffers huge economic and biodiversity losses from biological invasions. The complex topography, diverse native ecosystems, and increasing international trade of China with other countries provide numerous opportunities for the entry and colonization of invasive species. In fact, more than 750 invasive species were confirmed in China (http://www.chinaias.cn, accessed on 2019-6-5). Among these pests, almost half of the 100 World's Worst Invasive Alien Species were identified in China, including the notorious pest, the red imported fire ant, Solenopsis invicta. Solenopsis invicta is an ant species native to tropical regions of South America, and its original homeland was thought to be the Pantanal region of Brazil. The S. invicta invasion caused many problems with human health, public safety, agriculture, economy, and ecology around the world (Vinson 1997; 2012; Wojcik et al. 2001; Wang et al. 2019). For example, an investigation in 1999 showed that $S$. invicta infestation causes $\$ 38$ million loss on crops and livestock productions in Texas, USA (Lard et al. 2002). Moreover, the sting of $S$. invicta can cause skin redness, swelling, urticaria, allergic shock, or in the worst case, death (deShazo et al. 1984; deShazo and Banks 1994). In the United States, almost $40 \%$ of the population may be stung by fire ants each year in cities of the southeastern states (deShazo and Williams 1995). Investigation in four provinces of China showed more than a third of people in fire ant-infested areas have suffered stings, and about $10 \%$ of them have experienced fever and allergic reactions (Xu et al. 2012).

Solenopsis invicta was introduced to the United States in 1930s and infested more than 320 million acres of land in southern United States (Williams et al. 2003; Wetterer 2013). In the Americas, S. invicta was also introduced to Mexico and the West Indies (Wetterer 2013). In Oceania, S. invicta was found in Australia and New Zealand (Pascoe 2002; Henshaw et al. 2014), and New Zealand claimed that the S. invicta population there was eradicated successfully several years after invasion (Moloney and Vanderwoude 2010). In Asian countries, S. invicta was found in Taiwan province of China in 2003, then appeared in mainland China in 2004 (Zeng et al. 2005a). As a consequence of its continuous expansion in China, the Chinese government invested efforts in controlling $S$. invicta, however, this invasive species continued to expand its territory throughout the country. In 2017, Japan and South Korea, S. invicta was found in containers and within container yards in several ports, but populations did not become established (Lyu and Lee 2017; Ujiyama and Tsuji 2018). Bertelsmeier et al. (2018) indicated that invaded areas act as a bridgehead of alien ants and the recurrent bridgehead effects increased the global rates of alien ant invasions. With increasing international communication and newly infested areas of S. invicta, the opportunity of S. invicta invasion is also increasing for tropical and subtropical regions.

The emergency response and management against the invasive fire ants have been carried out since S. invicta were found in China. Technical officers from government agencies and entomologists from universities and research institutions were sent to the USA and Australia by the Ministry of Agriculture and Rural Affairs to learn how to deal with the $S$. invicta invasion. These activities helped Chinese experts realize that 
prevention and control of $S$. invicta is long-term work. After comparison and analysis of the situation of $S$. invicta at home and abroad, the aim of plant quarantine and management of $S$. invicta became clearer in China. It is impossible to eradicate $S$. invicta in most infested regions in some provinces and several isolated infested places in China where it has already become established. Here, we review the Chinese experiences in coping with the $S$. invicta invasion. We also put forward the challenges in managing $S$. invicta in China by offering suggestions to potentially solve the problem. Our focus is to discuss experiences and reflect on the lessons learned from S. invicta management in the context of potential fire ant invasion in tropical and subtropical countries.

\section{History, current situation and trend of S. invicta infestation in China}

The initial entry of $S$. invicta was firstly discovered in Taoyuan County and Chiayi County of Taiwan province between September to October 2003, where thorough investigation revealed that 4000 ha land were infested. A decade later, 10 counties with more than 60000 ha land were occupied by S. invicta in Taiwan province (http:// www.fireant.tw, accessed on 2019-6-5). In mainland China, S. invicta was first found in Wuchuan, Guangdong province in September 2004, where, at the end of 2014, 12680 ha land were infested (Lu 2014). Wang et al. (2018b) predicated that $32^{\circ} \mathrm{N}$ may be the northern limit boundary of the certain infestation zone and $34^{\circ} \mathrm{N}$ may be the northern limit boundary of possible infestation zones of S. invicta. In 2018, S. invicta were detected in over 390 counties of 15 provinces and regions including Zhejiang, Fujian, Jiangxi, Hunan, Hubei, Guangdong, Guangxi, Hainan, Chongqing, Sichuan, Guizhou, Yunnan, Taiwan, Hongkong, and Macau (Figs 1, 2) (Lu and Zeng 2015; Ministry of Agriculture and Rural Affairs of the People's Republic of China 2018). Investigation showed that the density of fire ant was approximately $0.9-11.3$ mound per $100 \mathrm{~m}^{2}$ (average 7.26) when first found in newly infected areas (Lu et al. 2008). Based on its geographical distribution, Lu (2014) estimated that the speed of invasion via human-assisted transport in mainland China was about $26.5 \mathrm{~km} / \mathrm{a}$ using the area sqrt method. Lu and Zeng (2015) estimated that S. invicta invasion remained at the stage of rapid expansion, through local and long-distance expansion, so that 20-30 counties may be infested per year in the future if appropriate actions will not be taken.

\section{The mechanism of Solenopsis invicta invasion in China}

\subsection{Invasive routine and expanded speed in China}

The origins of populations of $S$. invicta in China are important in the terms of tracing the source of the species and instigating future preventive measures. Several studies suggested that $S$. invicta populations in China may have originated from the USA (Ascunce et al. 2011; Yang et al. 2012; Zeng et al. 2005a; Zhang and Hou 2014). However, He 


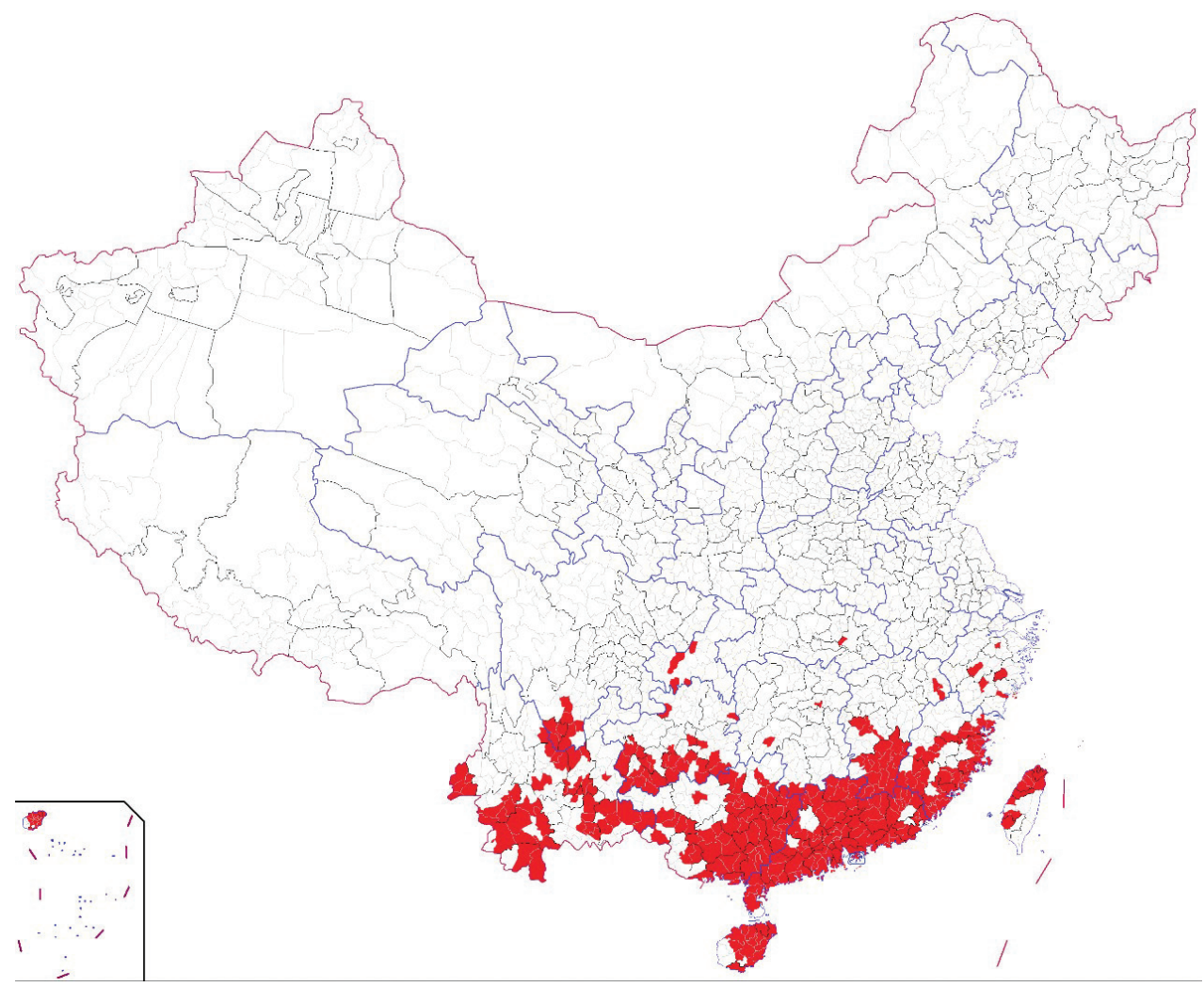

Figure I. Distribution of Solenopsis invicta in China in May, 2019. The red areas represent fire ant infested territories at a national level.

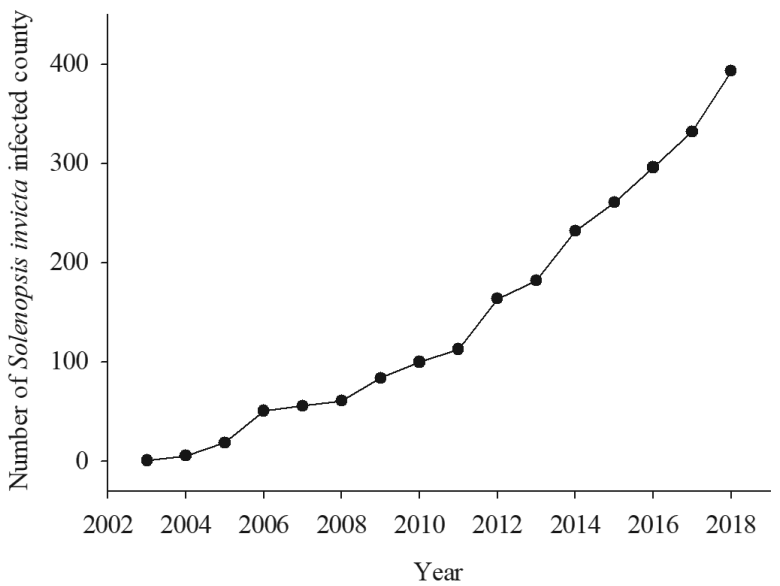

Figure 2. Growth dynamics of S. invicta infected counties from 2003 to 2018 . The data for infected counties in China quoted from Lu (2014), http://www.moa.gov.cn/, and http://www.fireant.tw. 
et al. (2006) indicated that South America may also have been a source of Chinese populations of this species. This conclusion was based on the analysis of mitochondrial cytochrome oxidase I (COI) of the $13 \mathrm{~S}$. invicta populations in newly invaded areas in mainland China. These findings indicated that the invasion history of S. invicta in China is complex with multiple invasions routes from other regions infected by $S$. invicta.

The growth in global trade and travel accelerated the spread of $S$. invicta from one infected region to another (Floerl et al. 2009; Ascunce et al. 2011). Investigation of Chinese quarantine agencies revealed that the interceptions of $S$. invicta from imported goods increased rapidly during 2005-2017, where importation of logs, wastepaper, and wood packing materials showed the greatest risk to introduce the invasive fire ants to China (Ma et al. 2010; Xian et al. 2019). On the other hand, in Chinese domestic settings, long-distance expansion of $S$. invicta relied mainly on potted plants, turf, recyclable waste, and transport of dairy cattle forage (Lu et al. 2008; Fig. 3). A previous study showed that the transportation of contaminated turf and nursery stock resulted in about $85 \%$ of new infections (Lu and Zeng 2015). Investigation of horticulture farms in Guangzhou and Shenzhen showed that several plant species have high infection rate of S. invicta compared to other garden plants, including Chamaedorea erumpens, Pachira macrocarpa, Rohdea japonica, Murraya exotica, Magnolia denudate, Fortunella japonica, Eucalyptus robusta seedlings, Phoenix dactylifera, Ficus benjamina, F. microcarpa, Melaleuca bracteate, Setaria viridis, and Podocarpus macrophyllus (Huang et al. 2007; Zhou 2009). Investigation on turf plantations and lawns in Guangzhou,

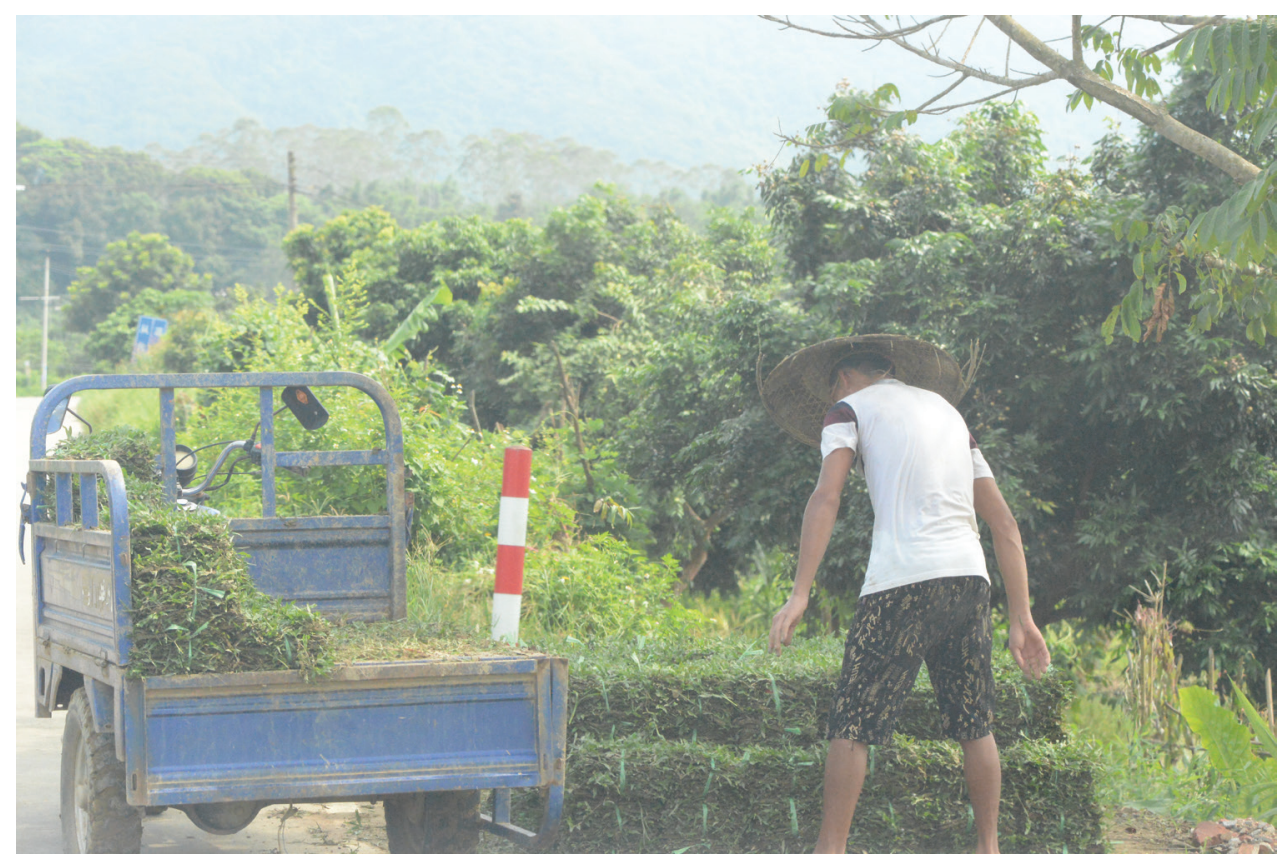

Figure 3. Sod and nursery stock transportation is the main pathway of Solenopsis invicta expansion in China (photo by Lei Wang). 
Shenzhen, and Huizhou also showed very similar results (Li et al. 2014). Furthermore, the same study recorded that the average fire ant colony density was 0.4 nest per 100 $\mathrm{m}^{2}$ in turf plantations ( $\mathrm{Li}$ et al. 2014). Solenopsis invicta is most likely to spread in other regions through turf transportation with inappropriate quarantine treatment. Zhang et al. (2015b) also found that potted plant and turf transportation, and recyclable waste transportation were the main routes of $S$. invicta invasion in Fujian province.

\section{The impact of Solenopsis invicta invasion in China}

Solenopsis invicta is a major threat to biodiversity, human health, and public safety in regions where it is introduced (Morrison et al. 1997; Vinson 1997; Wojcik et al. 2001). Here we summarized the impact of $S$. invicta in China.

\subsection{Risk in ecology}

In China, fire ants invasion has caused a severe reduction of diversity and abundance of arthropods (Wu et al. 2008; Wu et al. 2009; Song et al. 2010b; Xi et al. 2010a, 2010b; Huang et al. 2012a).

Investigation in China showed that $S$. invicta invasion presented a serious negative impact on the abundance, diversity, and richness of native ants in Litchi chinensis and Dimocarpus longan orchards, lawns, abandoned land, grassland, and residential areas. Ant species richness was reduced by more than 33\% in several habitats (Tsai et al. 2009; Jiang et al. 2010; Song et al. 2010; Wu et al. 2010; Lu et al. 2012a; Qi et al. 2015). As an aggressive species, S. invicta have a significant negative impact on the diversity index and evenness index of the ant communities within the $3 \mathrm{~m}$ of its mound (Wu et al. 2009). Similar to the findings of Porter and Savignano (1990), simple habitats, including abandoned lands and lawn, lost more native ant richness than complex habitats, including L. chinensis and D. longan orchards (Wu et al. 2008). As resource competition is the main driving mechanism for species replacement, the invasive $S$. invicta disturbs the mutualistic balance between native ant species and honeydewproducing hemipterans by monopolizing the honeydew. Since $S$. invicta can find food more rapidly than the native ant Tapinoma melanocephalum, this behavior can therefore cause a negative impact on the foraging behavior of the native species (Lu et al. 2012b; Wu et al. 2014a). In a few cases, however, some native ants can co-exist with $S$. invicta, including Pachycondyla luteipes, Pheidole piel, P. yeensi, Crematogaster macaoensis, Monomorium concolor, T. melanocephalum, Paratrechina flavipes, and Camponotus dolendus (Wang et al. 2019). Previous studies showed that some of these ants change their foraging and aggression behavior, as well as food preferences, in response to $S$. invicta invasion (Huang 2016; Cheng et al. 2019).

Solenopsis invicta invasion has a negative impact on other arthropods. For example, Huang et al. (2012b) found that S. invicta invasion decreased the diversity of 
spider communities in a cornfield, with a significant effect on the density of Oxyopex species. Also, $S$. invicta has a negative impact on the diversity and abundance of the arthropod communities in L. chinensis orchards, not only in the canopy of L. chinensis trees but also on the ground (Xi et al. 2010b). In a one-year investigation on abandoned land in Guangxi province, Zhang (2008) found that S. invicta invasion decreased the diversity of insect communities no matter how low the density of S. invicta mounds was. In Fujian province, Chen (2008) reported that $S$. invicta has a negative impact on the diversity of insect communities of grassland, bushes, bamboo groves, orchards, and roadsides dominated by insects belonging to Collembola, Labiduridae, Gryllidae, and Carabidae. These four groups of insects dominated non-infected area but $S$. invicta displaced three of the four groups, leaving only Collembola in the fire ant-infected area.

Plant seeds are important food sources of $S$. invicta. Zhang et al. (2015a) found that plant seeds consisted of 4.6-68\% of solid foraging materials for S. invicta in a mulberry orchard and on barren land in South China. Xu et al. (2009e) found plant seeds make up to $12 \%$ of refuse in middens of S. invicta. Solenopsis invicta also decreased plant seeds germination by moving and scarifying them. For example, Huang et al. (2010) found that germination rates of Sesamum indicum (sesame), Ageratum conyzoides (goatweed), and Pennisetum purpureum (napier grass) seeds decreased by $63 \%, 56 \%$, and 50\%, respectively.

Solenopsis invicta invasion also changes the physical and chemical properties of soil. The organic matter, alkalihydrolysable nitrogen, and available phosphorus decreased over time while the available potassium and soil acidity was raised after fire ant infestation in an orchard of L. chinensis (Xi et al. 2010b). These changes may cause a chain of reaction on the communities of organisms living in the soil.

\subsection{Loss in agriculture}

Using the plant seeds preference test, Huang et al. (2010) found that S. invicta preferred $100 \%$ of S. indicum (sesame) seeds, and so $82.4 \%$ and $64 \%$ of the seeds observed are scarified and not able to germinate, respectively. Sesamum indicum seeds are rich in oil, which might be a reason why $S$. invicta prefer to consume these seeds. In another field test, the number of seeds which failed to germinate increased 2.86 times and 1.21 times under heavy infection with $S$. invicta $\left(5\right.$ mounds per $100 \mathrm{~m}^{2}$ ) (Huang et al. 2014). Another field test showed that $S$. invicta and its mutualism with aphids disturb the flower-visiting behavior of insects on crops, causing approximately $35 \%$ of yield loss in mungbean (Wu et al. 2014b). Figure 4 shows workers of S. invicta attacking a Vigna unguiculata plant.

Although we did not get any authoritative data to show how much losses were attributed to $S$. invicta invasion in Chinese agriculture, a loss assessment in Fujian province showed that $S$. invicta has caused 744.70 Yuan/ha direct loss and 2756.48 Yuan/ ha indirect loss in its agriculture sector ( $\mathrm{Hu} 2008)$. 


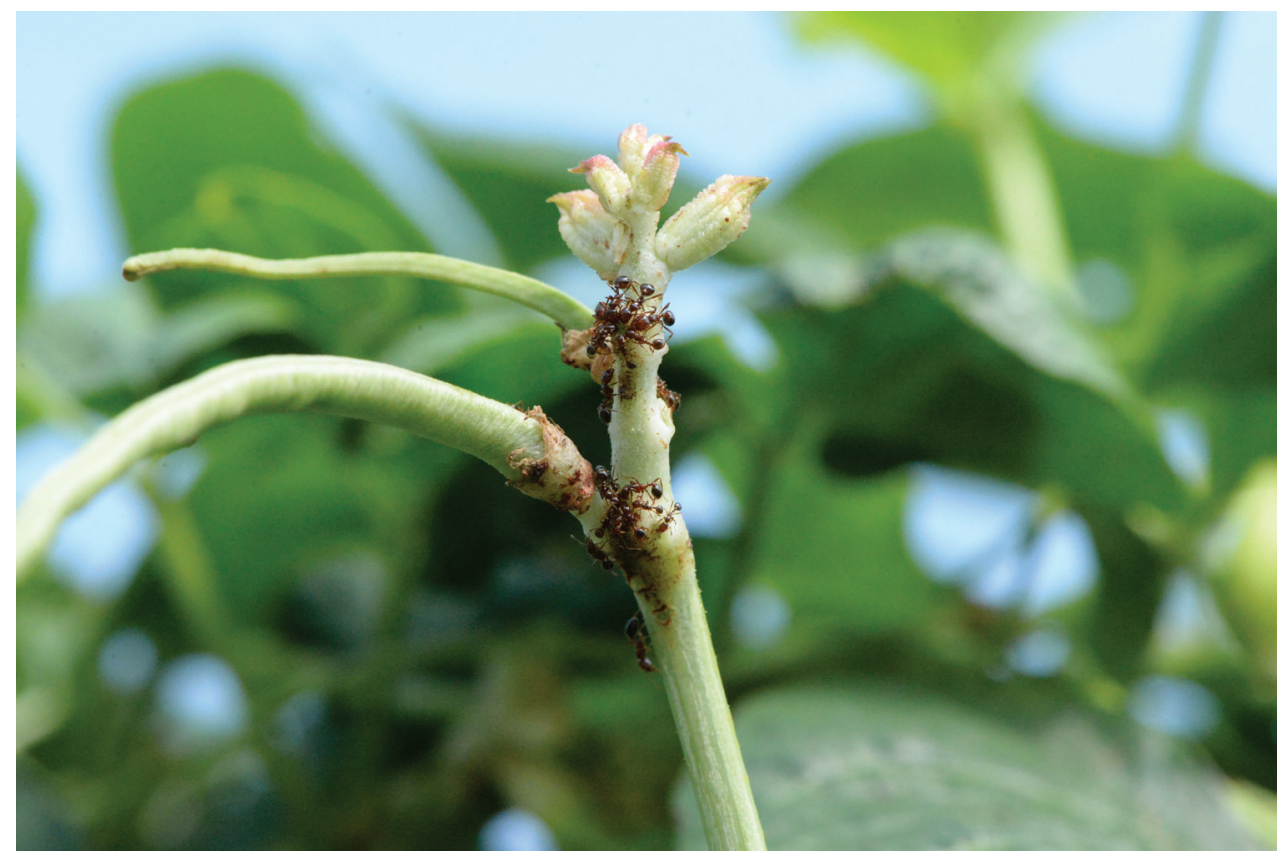

Figure 4. Solenopsis invicta workers attack a Vigna unguiculata plant (photo by Lei Wang).

\subsection{Threat in human health}

Solenopsis invicta is an aggressive species that may attack people upon contact. Humans who suffer from the sting of $S$. invicta can experience itchiness and redness, and most of the time, a white pimple may appear several hours after the sting (Fig. 5). Some people also experience serious hypersensitivity, including fever, urticaria, shock, and even death (Fig. 6). In China, greenbelts, farmland, and parks are the top three places where fire ant sting occurs (Zhao and Xu 2015). An investigation in 2004 showed that more than $30 \%$ of people in four provinces of China suffered from fire ant stings, and $10 \%$ of them experienced fever, with a few individuals experiencing systemic allergic reaction (Xu et al. 2012), and death (Zhang et al. 2006; Zhao and Xu 2015) (http:// www.jinciwei.cn/i239583.html, accessed on 2019-7-15). Hu (2008) indicated that one person could lose 83.80 Yuan after being stung by S. invicta; this would include charges for treatment and loss of working time.

\subsection{Threat in public safety}

In China, researchers found fire ant mounds in power facilities and transformer stations (Luo 2005; Zhao et al. 2008). In Boluo county, Guangdong province, 12 of 19 power facilities and transformer stations were infected by $S$. invicta, causing damage on wire and cable, cable boxes, power transformer boxes, and other facilities of power 


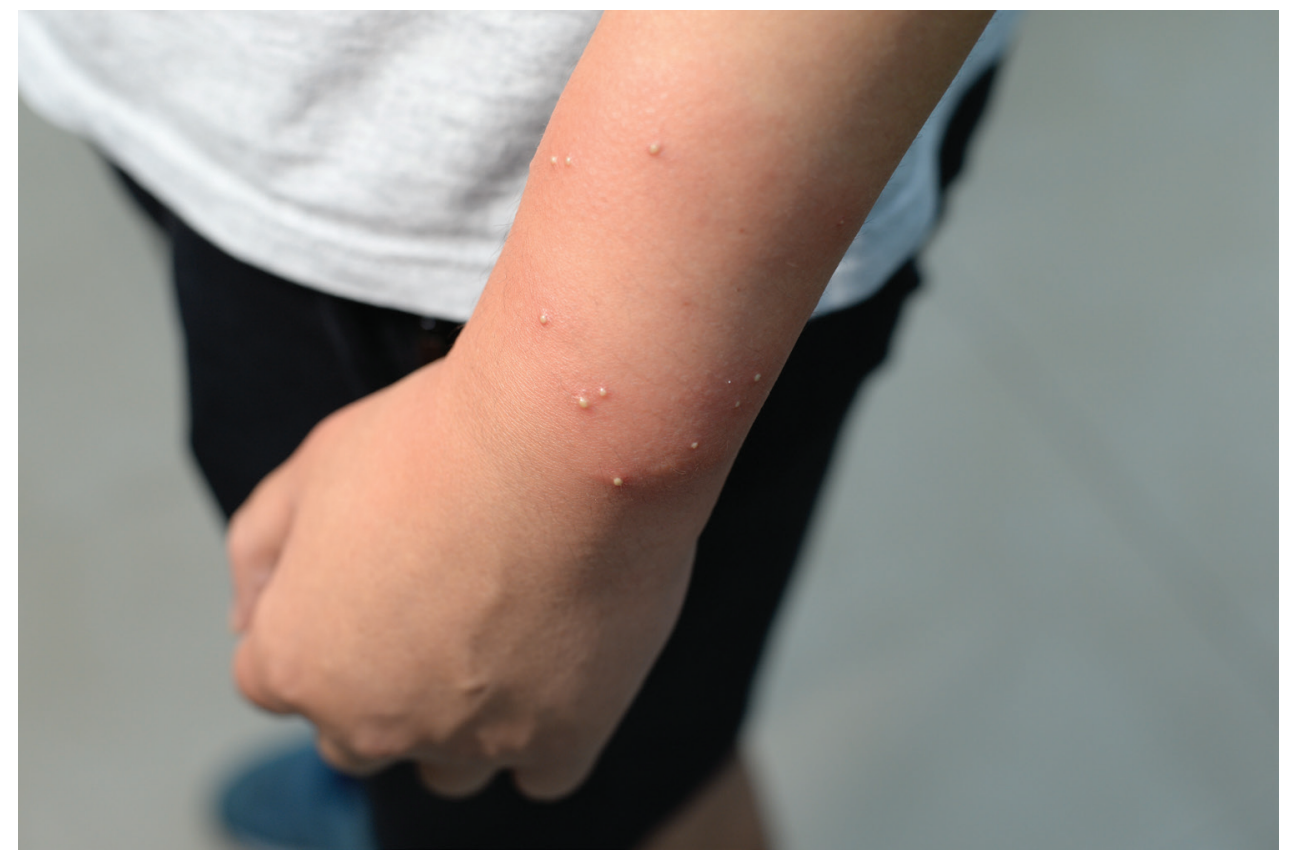

Figure 5. The typical symptom after Solenopsis invicta sting. A white pimple will appear in the place $S$. invicta sting several hours later (photo by Lei Wang).

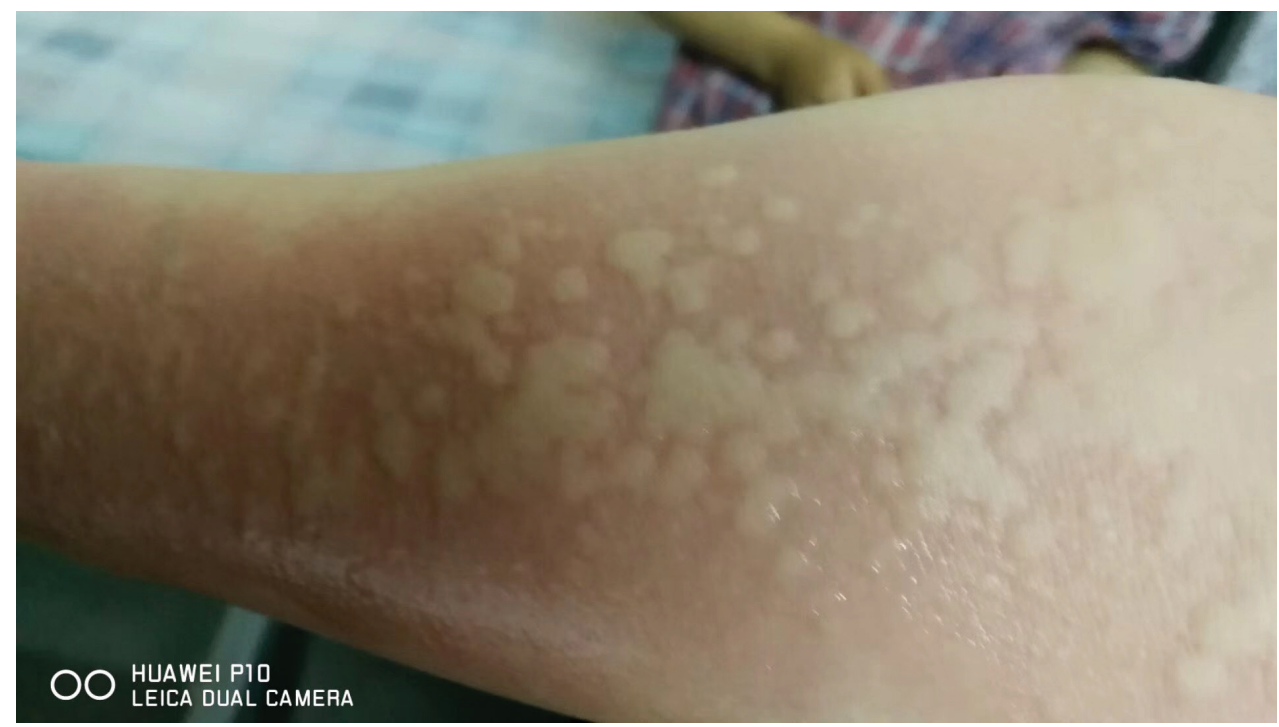

Figure 6. A person experienced a serious allergic reaction after $S$. invicta sting (photo by Shenlei Li).

stations (Luo 2005). Since S. invicta can be attracted to the electric field (Cui et al. 2018), people are concerned that fire ant may induce a short circuit that will result in power system failure. Figure 7 shows $S$. invicta workers attacking a cable box. 


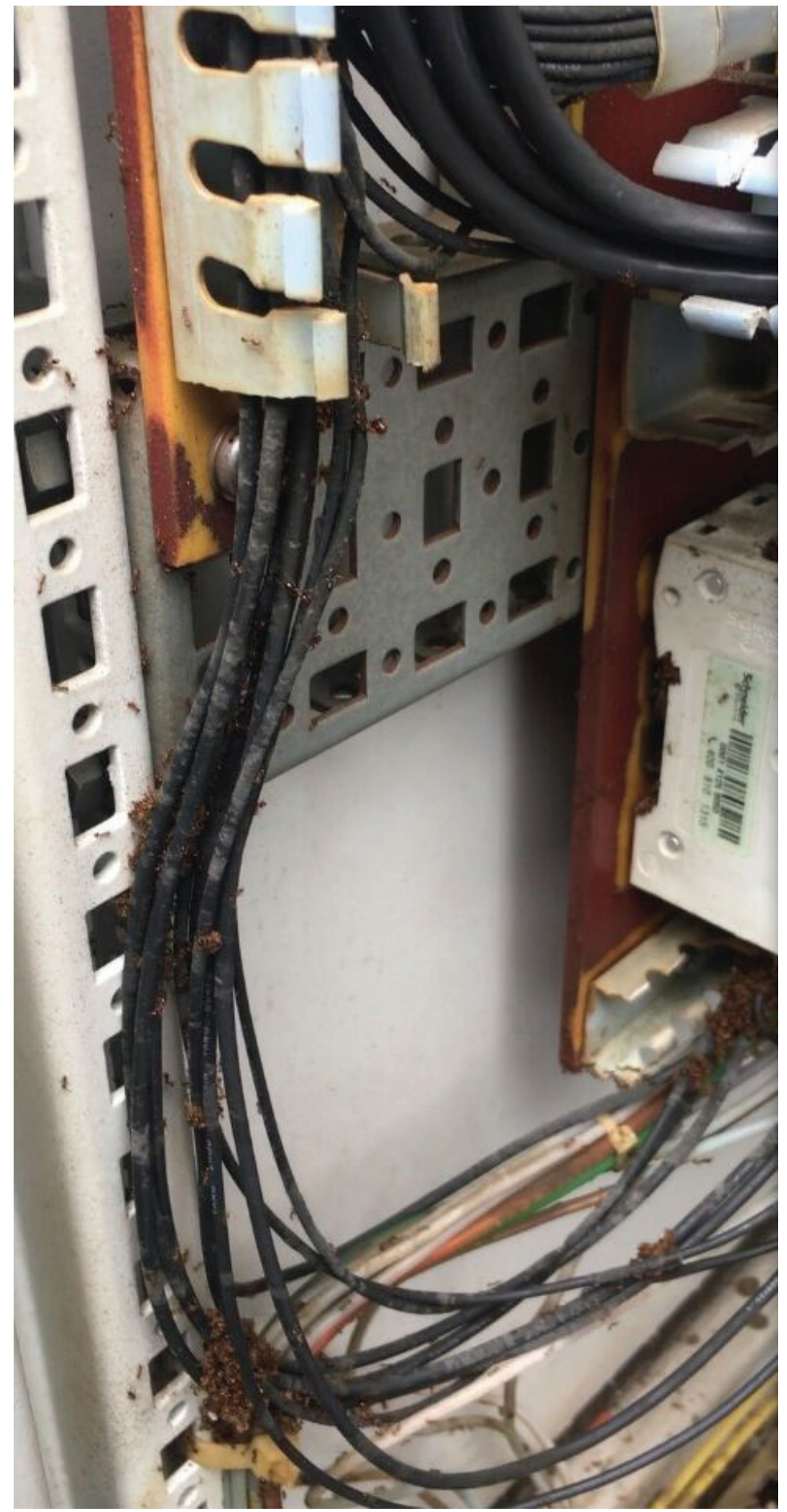

Figure 7. Solenopsis invicta workers attack a cable box (photo provided by Guangzhou Metro Group Co., Ltd). 
Dikes and dams are among the places with $S$. invicta mounds. An investigation in 2013 showed that 28 of 64 dikes and dams were infected by S. invicta in Guangdong province (Pan 2013). Solenopsis invicta can destroy electric facilities, sting the staff, and may threaten the stability of river banks (Pan 2013). Also, Chen et al. (2017) reported that a destroyed polyethylene gas tube caused a gas leak (Fig. 8). We do not have any reliable data on the economic loss associate with public safety concerns caused by $S$. invicta.

\section{Biology of S. invicta in China}

The creation of a suitable strategy for management of $S$. invicta would depend on the deep understanding of its biology and ecology and must be tailored to the regions where the invasive species is newly introduced. In China, many research institutions have focused their work on fire ant biology and ecology since the first reports of the $S$. invicta invasion.

Solenopsis invicta has two social forms, monogyne (having a single queen within a colony) and polygyne (having multiple queens within a colony), which both possess several distinct differences in terms of biology and dispersal abilities (Porter and Savi-

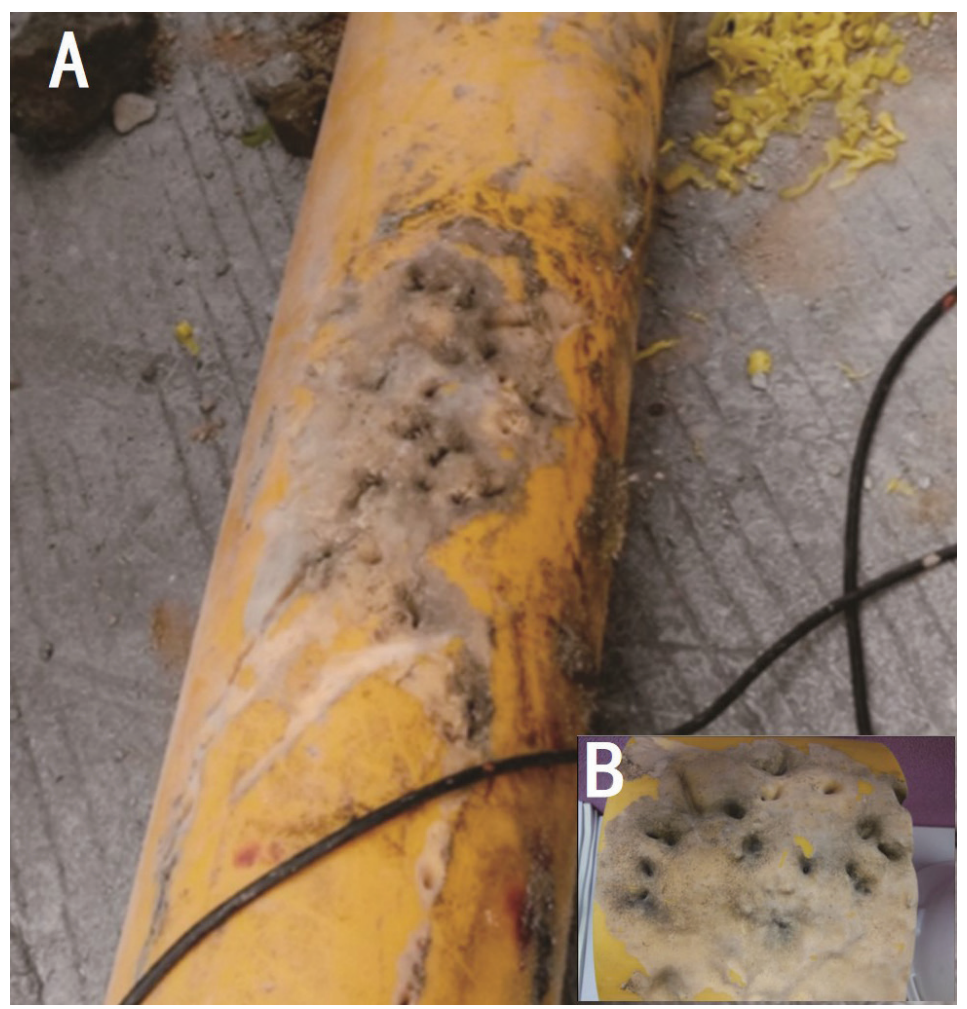

Figure 8. The PE gas tube was destroyed by Solenopsis invicta. A The position of destroyed position B The detail of the destroyed position) (photo from Chen et al. 2017). 
gnano 1990; Ross and Keller 2003). Although both monogyne and polygyne colonies have invaded China, it is the polygyne type that retains the dominant social form (Chen et al. 2006; Zeng et al. 2005b; Shao et al. 2008).

Previous studies have shown that the population and breeding dynamics of $S$. invicta consist of two peaks in a year, i.e., spring and autumn (Xu et al. 2009d); however, their nuptial flights occur throughout the year (Xu et al. 2009a). The foraging activity of $S$. invicta also consists of more than two peaks in a year, but the daily foraging activity and the number of foraging workers vary among seasons in south China ( $\mathrm{Li}$ et al. 2008; Chen et al. 2010; Jiang et al. 2011).

Wang et al. (2016) found that small workers serve as the main food transporters and that the cooperation of $S$. invicta was not well-coordinated in dealing with food transportation. Using sugar water to observe feeding behavior, Wang et al. (2018a) identified five foraging patterns and revealed that the feeding pattern is performed most frequently in the field. Another study on feeding behavior found that $S$. invicta prefers to collect liquid food in the field (Qiu et al. 2014c). Qin et al. (2019b) observed how fire ants transport food on vertical surfaces, leading to the basis of developing novel fire ant baiting systems placed on tree trunks. Qin et al. (2019a) also found that certain groups of workers have a burying behavior and that this behavior may suppress foraging activity. Research has also shown that the foraging gene of S. invicta (sifor) mediates environmental signals associated with temperature gradient and food-seeking behavior; hence, sifor may play an important role in the photoperiod response of this species (Lei et al. 2019; Zhou et al. 2019).

Honeydew is an important food resource of S. invicta (Zhou et al. 2012a, 2012b, 2012c). To acquire the honeydew resource, $S$. invicta excludes native ants from the honeydew-producing hemipterans and builds a stronger mutualistic interaction with the hemipterans (Zhou et al. 2014, 2017). Also, S. invicta can protect honeydew-producing hemipterans against their natural enemies by attacking their predators (Huang et al. 2011; Zhou et al. 2013; Cheng et al. 2015) and hide hemipterans in shelters from parasitic wasps (Zhou et al. 2012d). As ant-tending behavior produces positive effects on the physiological and behavioral performance of the mealybug Phenacoccus solenopsis, this hemipteran tends to excrete honeydew more frequently with lighter droplets rich in melezitose to attract more fire ant workers (Zhou et al. 2015). Therefore, mutualistic interactions between ants and hemipterans are mediated by the honeydew produced by the hemipterans (Zhou et al. 2012b).

The main chemical components of $S$. invicta venom are 2-methyl-6-alkyl or alkenylpiperidines (Chen et al. 2009). However, other pyridine alkaloids were also isolated and identified, including, 2-methyl-6-undecylpyridine, 2-methyl-6-tridecenylpyridine-isomer, 2-methyl-6-tridecenylpyridine-isomer, 2-methyl-6-tridecylpyridine, 2-methyl-6-pentadecenylpyridine-isomer, and 2-methyl-6-pentadecylpyridine (Chen et al. 2019a). Liu et al. (2017) suggested that by using the whole body solventsoaking method, an adequate amount of fire ant venom alkaloids can be extracted for chemical analyses and bioassays. Fox et al. (2018) also developed a straightforward method for extracting within minutes aculeate $S$. invicta venoms by centrifugation. 
The venom alkaloids of $S$. invicta have many functions. For example, an alkaloid isosolenopsin A from S. invicta queens could knockdown its competitors rapidly and plays a role in successful nest founding (Fox et al. 2019). Venom alkaloids can also inhibit germination and hyphal growth of entomopathogenic fungi (Obin and Vander Meer 1985). Research has shown that venom alkaloids inhibited the plant pathogen Pythium ultimum and bacterial canker of tomato, and thus there is the possibility for developing venom alkaloids as novel fungicides and bactericides (Li et al. 2012, 2013). Cuticular hydrocarbons (CHCs) are a type of chemicals that prevent desiccation, aside from playing a role in signal communication (Hu et al. 2017). Xu et al. (2018a) found that CHCs of S. invicta can retain more water under relatively higher temperature, which helps $S$. invicta in occupying warmer environment, and they concluded that $\mathrm{CHCs}$ played an important role in shaping the distribution of fire ants in the USA.

Aggressiveness is a very important weapon of fire ants in food competition and territory defense in the introduced regions. The aggressive activity of $S$. invicta can be affected by mound size, colony structure, habitat, temperature, humidity, degree of disturbance, and the use of pesticides (Gao 2007; Wang 2010). However, aggressiveness seemed unaffected by starvation and rafting (Cao et al. 2011; Huang et al. 2016c).

Resistance to adversity is an important trait for successful adaption of the invasive species in a particular region. Xu et al. (2009f) found that S. invicta improved their drought tolerance after a short period of non-lethal drought by maintaining low-level water consumption during the acclimation process. Solenopsis invicta also improves its cold and heat tolerance after a short period of non-lethal exposure to high- or lowtemperatures (Xu et al. 2009b, 2009c). These results imply that S. invicta can strongly adapt to extreme weather.

Necrophoric behavior is an important behavior aspect of S. invicta to avoid horizontal transmission of pathogens in the colony. Qiu et al. (2015) found that the presence of fungus-infected pupal corpses will accelerate necrophoric behavior. Solenopsis invicta receive linoleic and oleic acids at a minimum concentration of approximately $1 \mu \mathrm{g} / \mu \mathrm{L}$ as a chemical signal to aid necrophoric behavior (Qiu et al. 2015; Xu et al. 2018b). Fire ants sense the presence of oleic and linoleic acids by using the chemosensory protein gene Si-CSP1 (Qiu and Cheng 2017).

Understanding the mechanisms of insecticide metabolism will provide a theoretical basis for the rational usage of insecticides in controlling S. invicta. Research has shown that larvae and pupae were less sensitive to insecticides than adults (Guo et al. 2015; Xiong et al. 2019) as a result of the high activity of their metabolic enzymes (Yan et al. 2011). Miao et al. (2009) showed that acetylcholinesterase did not correlate with phoxim detoxification. Zhang et al. (2016b) indicated that the cytochrome P450 genes of S. invicta, including SinvCYP6B1, SinvCYP6A1, CYP4AB2, and SinvCY$P 4 G 15$, play an important role in enhanced metabolic detoxification of insecticides. After chlorpyrifos and fipronil exposure, increased transcription levels of cytochrome P450 cause increased O-demethylase activity, a process related to the detoxification of insecticides in S. invicta (Zhang et al. 2016a). 


\section{The responses of China on Solenopsis invicta invasion}

\subsection{Management agencies and research institutions}

Strong leadership, good organization, and coordination skills provide a guarantee on preventing $S$. invicta invasion. Specific research institutions are needed for strong scientific and technological support in combatting the spread of this species. For example, the Animal and Plant Health Inspection Service (APHIS) of the United States Department of Agriculture (USDA) is responsible in laying down operational responses against imported fire ants (i.e. S. invicta, S. richteri, and hybrids of these species) through strict quarantine activities (https://www.aphis.usda.gov/aphis/ourfocus/planthealth/plant-pestand-disease-programs/pests-and-diseases/imported-fire-ants, accessed on 2018-8-27). In Australia, the Australian Quarantine and Inspection Service (AQIS) of Department of Agriculture and Water Resources is the government agency responsible for the quarantine of S. invicta (https://www.daf.qld.gov.au/business-priorities/plants/weeds-pest-animalsants/invasive-ants/fire-ants/general-information-about-fire-ants, accessed on 2018-8-27).

Several attempts were also made in China to make further exploration in this field. In Taiwan province, the Fire Ant Control Organization was established through multiagency cooperation involving universities and government agencies of agriculture, environmental protection, health, education, economy, and traffic. The functions of the organization included the collaborative work of various agencies, creation of control plans and strategies, funds allocation, research, fire ant management, and the holding of meetings. In mainland China, specific organizations and research institutions were also established for fire ant management. The provincial government of every infected province established a leading group for fire ant control. The Red Imported Fire Ant Research Center of South China Agricultural University was established to provide scientific and technological support and counseling and services on fire ant management for the government, enterprises, and the public. The National Fire Ant Detection and Management Union was founded by the Ministry of Agriculture and Rural Affairs in September 2006, and the union was comprised of provincial plant quarantine agencies of Guangdong, Guangxi, Hunan, Fujian, Hainan, and research institutions, including Institute of Zoology, Chinese Academy of Science, and South China Agricultural University, among others. The aim and missions of the union are to provide guidelines for fire ant management, control training, detection, specimen identification, etc. The National Fire Ant Detection and Management Union gives strong technical support to the government to cope with the fire ant invasion, holds management training meetings for the public which teach ways to appropriately deal with fire ants.

\subsection{The formulation and implementation of management policies and technical plans}

In countries infested with $S$. invicta, such as the United States and Australia, there are strict quarantine regulations drawn up for pest control and management (https:// www.aphis.usda.gov/aphis/ourfocus/planthealth/plant-pest-and-disease-programs/ 
pests-and-diseases/imported-fire-ants, accessed on 2019-6-5; https://www.daf.qld.gov. $\mathrm{au} /$ business-priorities/plants/weeds-pest-animals-ants/invasive-ants/fire-ants/generalinformation-about-fire-ants, accessed on 2018-8-28). With reference to the experience and lessons learned from the United States and Australia, S. invicta was put on the list of quarantine pests in China, and the strictest quarantine management was implemented immediately after the first report of $S$. invicta. In response to $S$. invicta invasion, many rules and plans were formulated by administration departments and enforcement agencies, including the Ministry of Agriculture and Rural Affairs, General Administration of Quality Supervision, Inspection and Quarantine, National Forestry and Grassland Administration, and General Administrative Office of National Health and Family Planning Commission (http://www.moa.gov.cn/xw/zwdt/200603/t20060306_563900. htm; http://www.moa.gov.cn/xw/zwdt/200412/t20041208_283440.htm; http:// www.forestry.gov.cn/main/4818/content-797166.html). In addition, in provinces infected by $S$. invicta provincial governments issued a work program for red imported fire ant investigation, surveillance, and management, following the policies and rules of the Ministry of Agriculture and Rural Affairs. These policies and rules provided the basis and guarantee on red imported fire ant management.

\subsection{Emergency response for $S$. invicta infestation}

In China, epidemics of $S$. invicta are ranked as Level 1, 2, 3, or 4 following the "Contingency plans for emergency response on red imported fire ant" (http://www.moa.gov.cn/ nybgb/2005/derq/201806/t20180617_6152397.htm). Level 4 means that the invasive fire ant is in one county and that the county government or its agricultural agency must start a contingency plan to control its spread. Level 3 means that S. invicta is in two or more than two counties but these infected counties belong to the same prefecture; hence, the contingency plan for $S$. invicta control must start through the prefectural government or its agricultural agency. Level 2 means that $S$. invicta invasion is in different prefectures but in the same province, and thus the provincial government or its agricultural agency must start the contingency plan. Level 1 means S. invicta invasion is in different provinces, the Ministry of Agriculture and Rural Affairs starts the contingency plan. This emergency response system plays a key role in preventing the rapid expansion of $S$. invicta in China. This model could also become the blueprint in managing other new invasive pests in China.

\subsection{Framework of fire ant routine management}

Expansions of highly effective mechanisms and models designed for controlling the spread of $S$. invicta and preventing its entry to new regions are arduous tasks but need to be established urgently. In response to the invasion of S. invicta, China has dramatically launched several programs since 2004. There are three steps for the management of $S$. invicta, i.e., confirming the epidemic, formulating a scheme, and planning and 
organizing its implementation. In China, government agencies lead and are actively involved in all three management steps.

The current principle of routine fire ant management is dependent on the administration, i.e., fire ant management was launched by local county government where fire ant was invaded (Fig. 9). There are three government-levels for fire ant management: (1) the central government (mainly in charged by Ministry of Agriculture and Rural Affairs of China), (2) the provincial government (mainly in charged by Department of Agriculture and Rural Affairs of a province), and (3) the county government (mainly in charged by Bureau of Agriculture and Rural Affairs). The duty of the Ministry of Agriculture and Rural Affairs of the People's Republic of China is to draw policy, standards, and guidelines for fire ant management. Limited financial support was given in key regions or national demonstration areas for fire ant management. The duty of the Department of Agriculture and Rural Affairs, a provincial agency, includes the provision of financial support for management of key regions of the province, giving technical support and supervising and inspecting control efficiency of fire ant management in the province as a whole. The duty of the Bureau of Agriculture and Rural Affairs, a county agency, includes responses for fire ant management for the whole county by following the policy of the central government and provincial government. Other duties include providing financial support and organizing the management plan.

\subsection{Financial support}

Financial support is one of the key factors on fire ant eradication and management. For example, New Zealand spent three years and ca 7.41 million USD to eradicate $S$. invicta successfully from a $12.56 \mathrm{~km}^{2}$ area of Whirinaki, which means that New Zealand spent 0.20 million USD per $\mathrm{km}^{2}$ in one year (http://www.scoop.co.nz/stories/ PA0611/S00286.htm, accessed on 2019-6-5; http://b3.net.nz/gerda/refs/14.pdf, accessed on 2019-6-5). In China, Jiahe county of Hunan province spent three years and ca 82000 USD on an isolated infested area $\left(\mathrm{ca} 0.4511 \mathrm{~km}^{2}\right)$ to successfully eradicate S. invicta, which translates to ca 0.06 million USD per $\mathrm{km}^{2}$ spent in a year just for eradicating an isolated infested area (data was collected from Bureau of Agriculture and Rural Affairs, Jiahe county). At present, Australia is planning to spend ca. 300 million USD over 10 years to eradicate red imported fire ants from a $7800 \mathrm{~km}^{2}$ region in south-east Queensland (https://www.daf.qld.gov.au/business-priorities/biosecurity/invasive-plants-animals/ants/fire-ants/eradication/10-year-plan, accessed on 2019-6-5 ).

For many regions infested by fire ants, eradication is becoming impossible, and the local government instead runs a long-term management program that potentially consumes considerable financial resources. Shenzhen City is one of the best models in China. Shenzhen City spent ca 0.32 million USD to keep the fire ant under control in a $2000 \mathrm{~km}^{2}$ region in 2018, costing approximately 160 USD per $\mathrm{km}^{2}$ per year (data was collected from Shenzhen Agricultural Science and Technology Promotion Centre, http://www.szcast.com/index.html, accessed on 2019-6-5). 


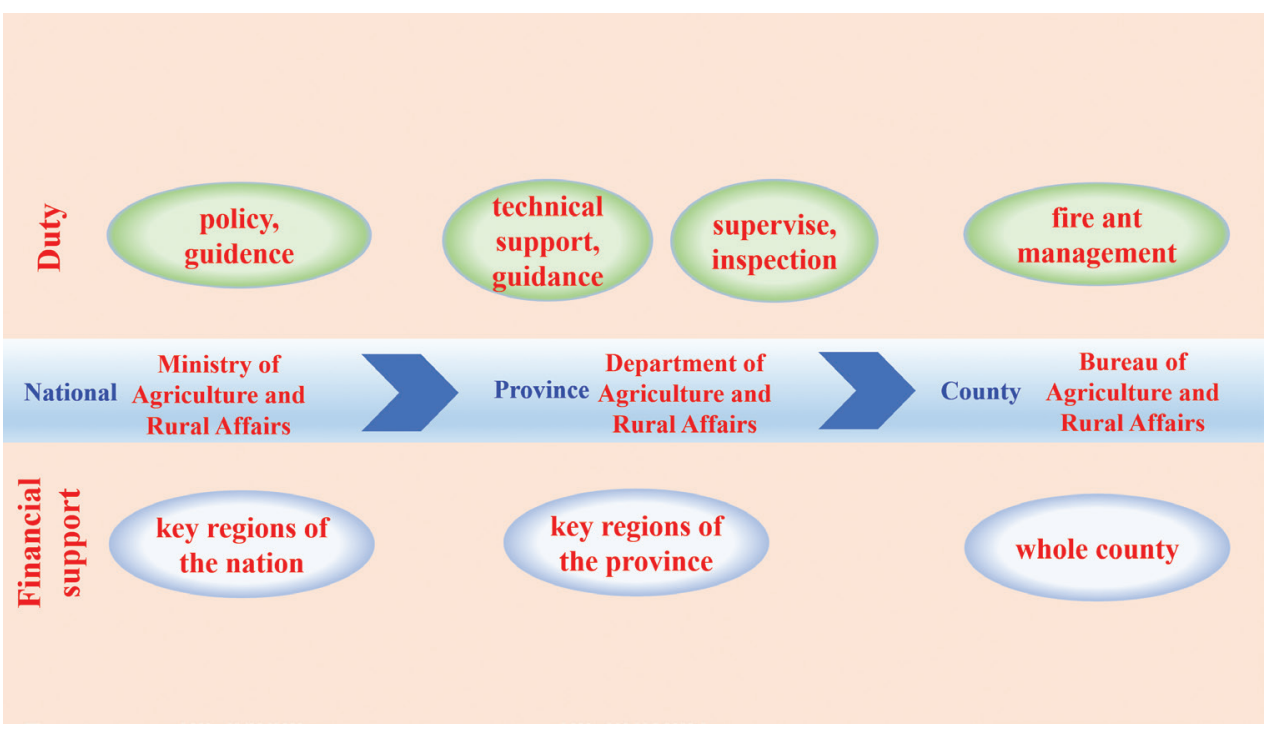

Figure 9. Framework of fire ant routine management in China. Different governmental levels have different duties.

\section{Current strategy for S. invicta management in China}

\subsection{Exploration for control methods of $S$. invicta}

Although 40 products were registered for management of S. invicta in China, the main active ingredients were only 3 or 4 types, i.e. indoxacarb, fipronil, hydramethylnon, and beta cypermethrin. Among these four, the application of fipronil was forbidden in the agricultural system (http://www.icama.org.cn/hysj/index.jhtml, accessed on 201912-10). The selection of effective ingredients was done in China. Previous reports have suggested that other insecticides have great potential for the management of $S$. invicta, including sulfoxaflor, dinotefuran, clothianidin, nitenpyram, thiamethoxam, ethiprole, chlorfenapyr, cyantraniliprole (Pan 2017; Pan et al. 2017; Du 2018; Zhou et al. 2018). Green insecticides were also evaluated for their effect on $S$. invicta. The toxicities of plant extracts derived from Lantana camara, Pronephrium megacuspe, Cinnamonum camphora, Murraya exotica, Viburnum odoratissimum, Michelia alba, and Periploca sepium were also tested (Zhong et al. 2008; Fu et al. 2015; Huang et al. 2016a, 2016b; Hui et al. 2014; Qin et al. 2018; Zhang et al. 2017b; Huang et al. 2019). Many of these plant extracts exhibited excellent fumigation and contact toxicity under laboratory condition. For example, an ethanol extract of the shrub L. camara exhibited 100\% killing effect against $S$. invicta workers in five days in an indoor experiment (Zhong et al. 2008). Volatiles from $M$. alba leaves caused $100 \%$ mortality of S. invicta workers in 16 $\mathrm{h}$ in a fumigation bioassay (Qin et al. 2018). Decylamine from Monomorium minimum show toxicity by causing a knockdown effect and suppressed the digging behavior in S. invicta workers (Wang and Chen 2015). Effects of flavoring agents were also evaluated by Zhang et al. (2017a), who found that 0.1 or $0.2 \mathrm{~g} / \mathrm{mL}$ erythritol caused $80 \%$ 
mortality among S. invicta workers after $72 \mathrm{~h}$ treatment. Furthermore, glycine and Guanosine 5'-monophosphate (GMP) exhibited high toxicities to S. invicta with $\mathrm{LC}_{50}$ values of $0.004 \mathrm{~g} / \mathrm{mL}$ and $0.02 \mathrm{~g} / \mathrm{mL}$, respectively (Huang et al. 2018).

Some research has also been done on repellence selection. Wang et al. (2012) found that $1000 \mu \mathrm{l} / \mathrm{mL}$ of Capsicum annuum (sweet pepper) oil showed $>90 \%$ repellent activity against $S$. invicta workers under laboratory conditions. Essential balm strongly repelled $S$. invicta workers even at the concentration of $0.5 \mu \mathrm{L} / \mathrm{cm}^{2}$ (Wen et al. 2016). The repellence effect of two food additives, ethyl anthranilate and butyl anthranilate, were even better than diethyltoluamide (DEET) against S. invicta (Chen et al. 2019b).

Studies on the biological control of $S$. invicta have been ongoing in China where entomopathogenic nematodes and fungi were evaluated. Zhang et al. (2010) found that $S$. invicta workers can protect the queen and its colony from the entomopathogenic nematodes Steinernema carpocapsae (strain AII) and S. scapterisci by decreasing the effect these nematodes on $S$. invicta. Many entomopathogenic fungi strains were evaluated for control of S. invicta under laboratory conditions, including Paecilomyces lilacinus, Matarhizium anisopliae, M. flavoviride, and Beauveria bassiana, among others (Li et al. 2007; Yang et al. 2009; Liu et al. 2010; Xu et al. 2013; Wang et al. 2018c). Some of them showed a good impact on $S$. invicta in the laboratory but had poor effect under field conditions, indicating that the social immunity of $S$. invicta may play a modulating role. Wang et al. (2015) reported that $S$. invicta may use the antimicrobial property of volatiles to fumigate their nest. Qiu et al. (2016) found that S. invicta workers exposed with $M$. anisopliae showed self-medication and increased interaction with their nestmates in response to infection by $M$. anisopliae. Also, these $M$. anisopliae-exposed $S$. invicta workers spent less time in the pupal chamber so that the healthy workers could perform more grooming behavior; thus, increased duration of grooming counteracted infection of pupae by M. anisopliae (Qiu et al. 2014a). Qiu et al. (2015) also found that $M$. anisopliae-infected pupal corpses accelerated the necrophoric behavior of S. invicta workers. Qiu et al. (2014b) showed that S. invicta avoids food contaminated with entomopathogenic fungi and speculated that $S$. invicta may discriminate entomopathogenic fungi based on the profile of their volatile organic compounds. To enhance the efficiency of controlling S. invicta using entomopathogenic fungi, Li et al. (2016) designed an injector to deliver entomopathogenic fungi spores into the nest; this strategy resulted in control effect in both laboratory and field conditions. A new microencapsulation method of $M$. anisopliae was obtained with improved stress resistance and insecticidal activity on $S$. invicta (Qiu et al. 2019). Fan et al. (2012) presented a strain of $B$. bassiana that expressed pyrokinin $\beta$-neuropeptide $(\beta-\mathrm{NP})$ and thereby increased its fungal virulence towards $S$. invicta. Also, the combination of entomopathogenic fungi with pesticides seem to be one of the best control strategies against S. invicta. Wang et al. (2016) found that $M$. flavoviride SM076 spores can be mixed with $0.1 \mathrm{mg} / \mathrm{mL}$ indoxacarb, $0.1 \mathrm{mg} / \mathrm{mL}$ pleocidin, and $1.0 \mathrm{mg} / \mathrm{mL}$ methoprene without any negative effect. Moreover, $M$. anisopliae M09 can mixed with $0.5 \mathrm{mg} / \mathrm{mL}$ indoxacarb, $0.1 \mathrm{mg} /$ $\mathrm{mL}$ abamectin, $0.01 \mathrm{mg} / \mathrm{mL}$ fenoxycarb, $0.5 \mathrm{mg} / \mathrm{mL}$ methoprene, and $0.05 \mathrm{mg} / \mathrm{mL}$ 
fipronil without any negative effect (Wang et al. 2016). Li et al. (2018) showed that the combination of $B$. bassiana spores and thiacloprid at a mass ratio of 8:2 demonstrated a very significant synergistic effect in laboratory and field conditions.

\subsection{Education}

Education is very important for invasive species management. After the pest was found in mainland China, the Ministry of Agriculture and Rural Affairs immediately announced the notice for the management of $S$. invicta. Then, several campaigns to inform the public about $S$. invicta were launched through various television commercials and leaflets. For example, several programs that introduce the biology and control methods of S. invicta were recorded and broadcast by China Central Television. These campaigns help the Chinese government to deliver messages to avoid panic by the public and to spread knowledge of the biology, behavior, and control of S. invicta. For instance, an intervention questionnaire (1715 valid questionnaires) in Shenzhen city showed that TV, internet, newspaper, and leaflets were the main ways residents received knowledge of $S$. invicta ( $\mathrm{Li}$ et al. 2011). The intervention indicated that public education was an important way to distribute information about this species. In an 2013 investigation in Nansha district of Guangzhou, 65.2\% of the total participants (2638 valid questionnaires) heard of S. invicta but $47.65 \%$ had no knowledge on the correct method for fire ant management (Wang et al. 2014). These investigations showed that the pubic was aware of $S$. invicta but had no correct skills in controlling infestations. The next step, therefore, should be to strengthen public education on fire ant management using both traditional and modern media. For instance, books, including "Fire Ant Monitor and Management", "Fire Ant Management", and "Red Demon: Red Imported Fire Ant Invasion", and a film, "Stopping Fire Ant Invasion", were published and distributed freely since 2016 in infested regions. The three books and the film will help people learn how to deal with fire ants.

Meanwhile, fire ant management training activities were also lunched in infested regions, where entomologists who specifically study $S$. invicta were invited to give educational seminars and field training to residents, staff of agricultural agencies, and pest control companies. The national fire ant management training also held an anniversary for the staff of the agricultural agencies. The training normally has two parts where the attendees received educational presentations and fact sheets about fire ants and then field demonstrations of the methods for fire ant control.

In China, S. invicta can spread a long distance by the transportation of contaminated turf and nursery stock (Lu et al. 2008). Hence, it is hard to control the fire ant expansion without the cooperation of stakeholders. Thus, quarantine agencies provide professional support and training on management of S. invicta to owners of turf and nursery stock farms. Meanwhile, a responsibility agreement was also signed with stakeholders for preventing the spread of fire ants. 


\subsection{Fire ant management}

\subsubsection{Plant quarantine}

Surveillance at Chinese ports of logs, wastepaper, and wood packing materials from $S$. invicta-infected regions have shown that these objects were high-risk for the entry of S. invicta into China (Ma et al. 2010). Huang and Sun (2006) indicated traditional quarantine management for imported goods are inadequate and resulted in the introduction of $S$. invicta into China. The constraints of the current quarantine requirements are increasingly massive due to interconnected global trade and travel. Zhang et al. (2007) suggested that quarantine procedures should not only give more attention to high-risk goods but also undertake proactive surveillance at ports of entry.

Domestically, transportation of infected garden plants and turf are considered the main vehicle the spread of fire ants (Lu et al. 2008). For example, an investigation in Guangdong showed that $28.4 \%$ of garden plant nurseries and $48.8 \%$ of turf farms were infested by S. invicta (Huang et al. 2007). Li et al. (2014) found that $85.2 \%$ of 122 newly introduced cases of $S$. invicta were caused due to garden plants and turf. It is important to kill the red imported fire ant in contaminated garden plants before they are planted; hence, the use of contact insecticides for quarantine treatment is suggested (Wang et al. 2011). Cooperation from stakeholders is also very important, including both customers and personnel from the garden plant nurseries.

\subsubsection{Population assessment}

Understanding the density, degree of damage, and boundary of occurrence is the first step for management of $S$. invicta. Populations can be estimated by scoring active $S$. invicta mounds, the number of workers per bait, and the percentage of bait with workers (Lofgren and Williams 1982; Vander Meer et al. 2007). In China, the protocol "Guidelines for quarantine surveillance of Solenopsis invicta Buren (GB/T 23626-2009)" was formulated and announced in 2009. The guidelines give criteria on regional surveillance, temporal suitability, surveillance tools, surveillance methods, specimen identification and preservation, surveillance record table, etc. These guidelines also provide standards to rank occurrence levels of $S$. invicta populations based on the number of workers per bait and the active mounds in a unit area. In Guangdong province, the local "Guideline for Delimiting and Management of Solenopsis invicta Infected Site, Area of Surveillance Regions" was also formulated and announced in 2013 (http://www.gdagri.gov.cn/zwgk/zcfg/zhfg/201708/ t20170811_602860.html, accessed on 2019-6-5). In this guideline, specific regulations were given on how to delimit sites infected by $S$. invicta and the area of surveillance regions, control measures of infected sites, and how to evaluate control effect.

In China, "Solenopsis invicta Occurrence Notification System" was also applied. A total of 2488 surveillance sites were set up in more than 230 counties nationally where the area under surveillance reached more than 0.6 million hectares (Lu and Zeng 2015; Ministry of Agriculture and Rural Affairs of the People's Republic of China 2018). Therefore, the system provides a favorable guarantee for the alerting of new introductions of S. invicta in China. 


\subsubsection{Chemicals application}

Chemical application is the main method in managing the expansion of fire ants, especially in newly invaded regions. Many chemicals are effective for control, including bifenthrin, cyfluthrin, cypermethrin, deltamethrin, fenvalerate, fluvalinate, lambdacyhalothrin, permethrin, s-bioallethrin, es-fenvalerate, tefluthrin, tralomethrin, carbaryl, and acephate (Wang and Zong 2006). In China, the guiding protocol "Pesticideguidelines for the field efficacy trials (2)-Part 149: insecticides against Solenopsis invicta Buren (GB/T 17980.149-2009)" was announced in 2009. This guideline gives criteria to evaluate the field efficacy of insecticides against $S$. invicta, which helps Chinese insecticide companies to develop effective insecticide products against $S$. invicta. An industry standard for the control of $S$. invicta is the "Guidelines for chemical prevention and control of Solenopsis invicta Buren (NY/T 2415-2013)", which was announced at 2013 by the Ministry of Agriculture and Rural Affairs of the People's Republic of China (Ministry of Agriculture and Rural Affairs of the People's Republic of China 2013). These guidelines not only give criteria on strategy, optimum control period, control techniques, and matters needing attention in chemical control, but also recommend active ingredients for the control of the species, including bifenthrin, cyfluthrin, avermectin, spinosad, indoxacarb, sulfluramid, fipronil, and rotenone.

In the first few years after $S$. invicta was found in mainland China, pesticides for $S$. invicta control were classified as special-need pesticides by the Ministry of Agriculture and Rural Affairs so that companies could put a certain number of specific pesticides on the market with a temporary registration certification (Wang and Zong 2006). This policy not only minimized the hazards caused by $S$. invicta but also prevented its quick spread at the beginning of its invasion in China. Currently, 36 products from 22 companies are registered and available for managing $S$. invicta in mainland China. The active ingredients of these products include sulfluramid, indoxacarb, fipronil, hydramethylnon, beta-cypermethrin, spinosad, imidacloprid, and chlorpyrifos (www.icama. org.cn, accessed on 2019-6-5).

Toxic bait and surface treatments, including liquid mound drench and application of granules or dusts, are the main methods for control of S. invicta (Drees et al. 2013). Surface treatments are used as contact insecticides to eliminate $S$. invicta quickly, but most of them are used as individual mound treatment (Drees et al. 2013). Toxic bait works slowly, but it is effective and is also suitable for applications over large areas (Vogt et al. 2003). Soon after the initial invasion by S. invicta, Chinese scientists realized that not all methods used in other countries in the control of S. invicta were well suited in China. For example, the current use of individual mound drench is not recommended in China because previous experiences showed that residents had difficulty in learning the correct application of mound drench, which, in effect, eventually helped in the spread of S. invicta. Mound drench also needs too much water (about 10-20 L water for a mound) (Liu et al. 2006), contributes to environmental pollution, and causes harmful effects to the native arthropods (Liu et al. 2006; Yu et al. 2015). The most important limitation of this method is it cannot be used over wide areas. Currently, baits and contact dust are the main products for managing S. invicta in China. 
The two-step method developed in the Unites States is one of the main and most effective methods for management of $S$. invicta. It involves a combination of contact dust and baits. i.e., "Step 1. broadcast a fire ant bait once or twice a year to reduce fire ant colonies by 80 to 90 percent. Step 2. Treat nuisance mounds or colonies that move into the bait-treated areas. Step 2 may not be needed." (http://articles.extension.org/ pages/14345/fire-ant-control:-the-two-step-method-and-other-approaches). Following the example used in the United States, a modified two-step method was developed in China. Step 1: whole area control. Broadcast a bait in areas with high densities of S. invicta or apply bait on individual mounds in areas with low densities. Meanwhile, contact dust is used to treat individual mounds that are easy to handle. Step 2: Key area control. After 4-6weeks, the population of S. invicta is assessed. Then, the remaining parts of the area with a high population of S. invicta is treated by bait and the individual mounds is treated by contact dust. After the two steps, fire ant colonies can be reduced by as much as $90 \%$. The cycle of the two-step method can run again and again until S. invicta population is under control or eradicated in the treated area.

\subsubsection{Model for fire ant management in China}

The main system for managing $S$. invicta in China is hierarchical from top to down, i.e., the local government provides the financial support and the agricultural sectors (such as the Department of Plant Protection and Plant Quarantine, Agricultural Agency of county government), purchases the pesticides and management tools, and distributes these to the organizations of mass self-government (such as resident committees). However, this system is not very suitable for the management of $S$. invicta. Here are the main shortcomings: 1) basic-level agricultural agencies have a hard time comprehensively and effectively managing $S$. invicta because these agricultural agencies have limited human resources to oversee the huge and complicated job of managing all pests. This may result in a scenario where some staff may lack the professional ability to involve, guide, and supervise on management of $S$. invicta. 2) The field workers involved in the management of this species are always temporary employees in the basic-level government. Even with professional training, most workers still cannot fully master the technique and, as a result, pesticide use has always been a waste due to improper application. For instance, an investigation found that the control efficacy was only $20-65 \%$ when control was organized and operated by resident committees (personal communication).

Currently, professional pest control organizations are involved in the management of S. invicta in some provinces. In this system, the government agencies must create control plans and goals, review and approve the implementation plans that are provided by pest control organizations, inspect and supervise the implementation process, and check the control efficiency. The professional pest control organizations must make implementation plans, implement the management plans, and follow the goals of the government agencies. A third party, which is also the professional organization, was introduced by government agencies to inspect the implementation process and check the control efficiency. The professional pest control organizations have the professional 
skills to run an effective measure against $S$. invicta. This system does not only easily achieve the aim of managing $S$. invicta but also saves manpower, pesticides, and financial resources. The model is already running in several provinces and shows good effectiveness (http://www.hnjh.gov.cn/jhzf/2/3723/3757/3995/content_280184.html, http:// www.ccgp.gov.cn/cggg/dfgg/jzxcs/201812/t20181213_11335311.htm; http://www. sx.gov.cn/art/2018/7/2/art_1463355_19027725.html, http://www.changsha.gov.cn/

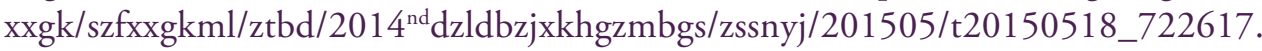
html, accessed on 2019-6-5).

The model was also designed and implemented for area-wide suppression or eradication of fire ants in China. When the control strategies for S. invicta are formulated, several factors are taken into consideration, including the distribution pattern of the infestation (whether widely distributed or localized), the environmental characteristics of infested area (complexity of habitat), and the characteristics of the occurrence of $S$. invicta (mounds are easy or difficult to find). Inspections of the whole given area are conducted at the onset of the program to identify unreported infestations. Then, plant quarantine is strictly implemented to prevent dispersal of $S$. invicta in the given areas. Education of residents about the control measure follows. The new two-step method is then applied to the area of infestation. After one cycle of the new two-step method, the inspections of the whole given area are conducted again to evaluate the efficiency of the control and the situation of the infestations. These control steps can be applied in the infected area over and over until the aim is achieved. The model has been conducted in fire ant management programs and has been successful. For example, in the Tianhe District of Guangzhou after using the model for five months, from June to October 2013 , the active mound of $S$. invicta reduced by $99.3 \%$ and the number of active fire ant workers reduced by $98.4 \%$ (unpublished data). In Hunan province, the agricultural agency of Jiahe county used the model and successfully eradicated $S$. invicta from a 45-ha region (http://www.hnjh.gov.cn/jhzf/2/3723/3757/3995/content_280184. html, access on 2019-6-5).

\section{Challenges}

Since the discovery of $S$. invicta in China, great efforts have been made to control and prevent its invasion and expansion. To date, safe and effective technology systems designed for monitoring, quarantine, emergency response, and eradication has been developed. These technology systems give strong support to the management of $S$. invicta, although fire ants still expand their territory within China. Based on past experiences of fire ant management programs in China, the strategies below might help the country in better responding to the threat of invasion by S. invicta.

First, plant quarantine should be put in place. Poor fire ant management and lack of plant quarantine for seedlings remain one of the important reasons why S. invicta continues to quickly expand its territory in China. Long-distance domestic transportation of potted flowers, turf, nursery stock, and waste materials is the main means of dis- 
persal for this species. Urbanization in China has increased the requirement for potted flowers, turf, and nursery stock and has accelerated the spread of fire ants. Meanwhile, more than 10 million landscaping seedlings are transferred from S. invicta-infested regions to uninfested regions every year in China, and many of these plants may not get the appropriate quarantine treatment because of lack of funds and a shortage of human resources. Also, interceptions of S. invicta in many Chinese ports has increased in cargo originating from other countries and regions. Therefore, the management of fire ant population in farms producing seedlings, effective quarantine technology system, and quarantine model should be strengthened and developed, as good management and quarantine can slow down the speed of $S$. invicta.

Second, the fire ant management system of government agencies should be updated. Various government agencies, for example agricultural and forestry, are involved in the management of S. invicta. However, cooperation among different local government agencies is not well executed, which has resulted in poor control of S. invicta in some regions. For fire ants to be eradicated at all points and in all regions, local government agencies should update the monitoring system, as well as its management, to avoid fire ants from reinfecting regions.

Third, developing more effective pesticides and applied methods is important to curb the spread of $S$. invicta. Traditional management methods are time consuming and laborious, especially in large areas with a high density of $S$. invicta. The development of rapid detection of nests is important for assessing control efforts and monitoring dispersal. Satellite aerial imagery could be used to assess the distribution of $S$. invicta mounds on a large scale (Vogt 2004a, 2004b), in addition to the deployment of trained dogs and spectrum analysis technology to inspect and count mounds (Lin et al. 2011; Wu et al. 2014c). Other new technologies are needed for rapid and accurate detection of mounds, thus facilitating precise, targeted insecticide treatments. Meanwhile, to reduce both environmental and economic losses related to chemical use, new management strategies and environmentally friendly insecticides are needed, especially for aquafarm, drinking water source areas, organic farms, and natural reserves.

Fourth, Korzukhin et al. (2001) predicted that the range of S. invicta in the eastern United States will expand over the next century due to climate change. A significant warming trend also has occurred throughout China over the past 20 years (Yu et al. 2011). With changes in the global weather, different types of ecological regions may be invaded by $S$. invicta, and S. invicta will likely adapt to new habitats and increase its impact on ecosystems.

\section{Acknowledgements}

We thank Dr Jian Chen, USDA-ARS, Stoneville, Mississippi, USA for critical reviews of the manuscript. This project was supported by Natural Science Foundation of Guangdong Province (Grant No. 2018A030313823), and Agricultural Science and Technology Innovation and Extension Project of Guangdong Province (Grant No. 2018LM2161). 


\section{References}

Ascunce MS, Yang CC, Oakey J, Calcaterra L, Wu WJ, Shih CJ, Goudet J, Ross KG, Shoemaker D (2011) Global invasion history of the fire ant Solenopsis invicta. Science 331: 1066-1068. https://doi.org/10.1126/science.1198734

Bertelsmeier C, Ollier S, Liebhold AM, Brockerhoff EG, Ward D, Keller L (2018) Recurrent bridgehead effects accelerate global alien ant spread. Proceedings of the National Academy of Sciences of the United States of America 115: 5486-5491. https://doi.org/10.1073/ pnas. 1801990115

Cao L, Kuang B, Yang J, Song Y, Xu Y (2011) Effect of starvation on the contact-free aggressive behavior and predation activity of Solenopsis invicta (Hymenoptera: Formicidae). Sociobiology 57: 461-469.

Chen H, Luo L, Xiong H (2010) The outing activity of worker ants and nuptial flight of alates in the red imported fire ant, Solenopsis invicta (Hymenoptera: Formicidae) in Guangzhou area, Southern China. Acta Entomologica Sinica 53: 449-456.

Chen J (2008) The restoration of arthropods diversity in different habitat after the regression of red imported fire ant (Solenopsis invicta Buren). Fujian Agriculture and Forestry University (Fuzhou): 1-2.

Chen J, Cantrell CL, Shang HW, Rojas MG (2009) Piperideine alkaloids from the poison gland of the red imported fire ant (Hymenoptera: Formicidae). Journal of Agricultural and Food Chemistry 57: 3128-3133. https://doi.org/10.1021/jf803561y

Chen J, Zhao Y, Li XC, Zhao JH (2019a) Pyridine alkaloids in the venom of imported fire ants. Journal of Agricultural and Food Chemistry 67: 11388-11395. https://doi.org/10.1021/ acs.jafc. 9 b03631

Chen JS, Shen CH, Lee HJ (2006) Monogynous and polygynous red imported fire ants, Solenopsis invicta Buren (Hymenoptera: Formicidae), in Taiwan. Environmental Entomology 35: 167-172. https://doi.org/10.1603/0046-225X-35.1.167

Chen SQ, Chen HY, Xu YJ (2019b) Safe chemical repellents to prevent the spread of invasive ants. Pest Management Science 75: 821-827. https://doi.org/10.1002/ps.5184

Chen X, Zhao Q, Tang Q (2017) Damage of Solenopsis invicta on PE gas tube and its management. Gas Technology 10: 10-13.

Cheng D, Chen S, Huang Y, Pierce NE, Riegler M, Yang F, Zeng L, Lu Y, Liang G, Xu Y (2019) Symbiotic microbiota may reflect host adaptation by resident to invasive ant species. PLoS Pathogens 15: e1007942. https://doi.org/10.1371/journal. ppat. 1007942

Cheng SJ, Zeng L, Xu YJ (2015) Mutualism between fire ants and mealybugs reduces lady beetle predation. Journal of Economic Entomology 108: 1560-1569. https://doi.org/10.1093/ jee/tov1 17

Cui C, Zeng L, Lu YY, Xu YJ (2018) Effect of eletric field on the aggregation of Solenopsis invicta workers. Journal of Environmental Entomology 40: 809-814.

deShazo RD, Banks WA (1994) Medical consequences of multiple fire ant stings occurring indoors. Journal of Allergy \& Clinical Immunology 93: 847-850. https://doi. org/10.1016/0091-6749(94)90376-X 
deShazo RD, Griffing C, Kwan TH, Banks WA, Dvorak HF (1984) Dermal hypersensitivity reactions to imported fire ants. Journal of Allergy \& Clinical Immunology 74: 841-847. https://doi.org/10.1016/0091-6749(84)90188-X

deShazo RD, Williams DF (1995) Multiple fire ant stings indoors. Southern Medical Journal 88: 712-715. https://doi.org/10.1097/00007611-199507000-00003

Drees BM, Calixto AO, Nester PR (2013) Integrated pest management concepts for red imported fire ants Solenopsis invicta (Hymenoptera: Formicidae). Insect Science 20: 429-438. https://doi.org/10.1111/j.1744-7917.2012.01552.x

Du Y (2018) Toxicity of 4 kinds of pyrrole insecticides on Solenopsis invicta Buren. South China Agricultural University (Guangzhou): 2-6.

Fan Y, Pereira R, Kilic E, Casella G, Keyhani N (2012) Pyrokinin beta-neuropeptide affects necrophoretic behavior in fire ants $(S$. invicta), and expression of beta-NP in a mycoinsecticide increases its virulence. PLoS One 7: e26924. https://doi.org/10.1371/journal. pone. 0026924

Floerl O, Inglis GJ, Dey K, Smith A (2009) The importance of transport hubs in steppingstone invasions. Journal of Applied Ecology 46: 37-45. https://doi.org/10.1111/j.13652664.2008.01540.x

Fox EGP, Wu X, Wang L, Chen L, Lu YY, Xu Y (2019) Queen venom isosolenopsin A delivers rapid incapacitation of fire ant competitors. Toxicon 158: 77-83. https://doi. org/10.1016/j.toxicon.2018.11.428

Fox EGP, Xu M, Wang L, Chen L, Lu Y-Y (2018) Speedy milking of fresh venom from aculeate hymenopterans. Toxicon 146: 120-123. https://doi.org/10.1016/j.toxicon.2018.02.050

Fu J, Tang L, Li W, Wang K, Cheng D, Zhang Z (2015) Fumigant toxicity and repellence activity of camphor essential oil from Cinnamonum camphora Siebold against Solenopsis invicta workers (Hymenoptera: Formicidae) Journal of Insect Science 15: 129. https://doi. org/10.1093/jisesa/iev112

Gao Y (2007) Studies on the activity of red imported fire ant Solenopsis invicta Buren workers. Anhui Agricultural University (Hefei): 2-6.

Guo W, Liu J, Cui R, Zeng X (2015) Susceptibility of different castes of the red imported fire ant (Solenopsis invicta Buren) to insecticides Chinese Journal of Applied Entomology 52: 1392-1396.

He X, Lu YY, Zhang W, Zeng L (2006) Three haplotypes found in populations of the red imported fire ant invading China. Acta Entomologica Sinica 49: 1046-1049.

Henshaw MT, Kunzmann N, Vanderwoude C, Sanetra M, Crozier RH (2014) Population genetics and history of the introduced fire ant, Solenopsis invicta Buren (Hymenoptera: Formicidae), in Australia. Australian Journal of Entomology 44: 37-44. https://doi. org/10.1111/j.1440-6055.2005.00421.x

Hu L, Vander Meer RK, Porter SD, Chen L (2017) Cuticular hydrocarbon profiles differentiate tropical fire ant populations (Solenopsis geminata, Hymenoptera: Formicidae). Chemistry \& Biodiversity 14: e1700192. https://doi.org/10.1002/cbdv.201700192

Hu S (2008) The damage risk and loss assessment of adventive organism red fire ant, Solenopsis invicta Buren, in Fujian. Fujian Agricultural and Forestry University (Fuzhou): 34-44. 
Huang J, Xiao C, Zhang Z (2019) Insecticidal activity and behavior inhibition of the red imported fire ant by Strophanthus divaricatu. Guangdong Agricultural Sciences 46: 106-113.

Huang J, Xu Y, Lu Y, Zeng L (2012a) Effects of Solenopsis invicta invasion on the diversity of spider communities in a corn field. Yingyong Shengtai Xuebao 23: 1111-1116.

Huang J, Xu Y, Liang G, Lu Y, Zeng L (2014) Effects on the germination of two dry land crop seeds of Solenopsis invicta Buren. Journal of Biosafety 23: 88-92.

Huang J, Xu Y, Lu Y, Liang G, Zeng L (2011) Effects of the invasive ant Solenopsis invicta (Hymenoptera: Formicidae) on Menochilus sexmaculatus (Coleoptera: Coccinellidae) as a predators of Aphis craccivora (Hemiptera: Aphididae) in laboratory conditions. Sociobiology 57: 565-574.

Huang J, Xu Y, Lu Y, Zeng L (2012b) Effect of Solenopsis invicta invasion on the diversity of spider communities in a corn field. Chinese Journal of Applied Ecology 23: 1111-1116.

Huang J, Xu Y, Zeng L, Liang GW, Lu Y (2010) Selective feeding of Solenopsis invicta on seeds of eight plant species and their influences on germination. Journal of Environmental Entomology 32: 6-10.

Huang J, Zeng L, Lu Y (2007) Infestation probability of the red imported fire ant, Solenopsis invicta, in nursery and stocks. Chinese Bulletin of Entomology 44: 375-378.

Huang P, Sun H (2006) Thinking about the management of imported plant quarantine from fire ant infested China. China Inspection and Quarantine: 17-18.

Huang R, Li Z, Wang S, Fu J, Cheng D, Zhang Z (2016a) Insecticidal effect of volatile compounds from plant materials of Murraya exotica against red imported fire ant workers. Sociobiology 63: 783-791. https://doi.org/10.13102/sociobiology.v63i2.972

Huang S, Fu J, Wang K, Xu H, Zhang Z (2016b) Insecticidal activity of the methanol extract of Pronephrium megacuspe (Thelypteridaceae) and its active component on Solenopsis invicta (Hymenoptera: Formicidae) Florida Entomologist 99: 634-638. https://doi. org/10.1653/024.099.0408

Huang Y (2016) Behavioral adaption and mechanism of native ants on the invasion of Solenopsis invicta Buren. South China Agricltural University (Guangzhou): 2-6.

Huang Y, Chen S, Li Z, Wang L, Xu Y (2018) Effects of flavor enhancers on the survival and behavior of the red imported fire ant, Solenopsis invicta (Hymenoptera: Formicidae). Environmental Science and Pollution Research 25: 21879-21886. https://doi.org/10.1007/ s11356-018-2276-8

Huang Y, Zhu S, Tan D, Zeng L, Wang L, Xu Y (2016c) Aggression of Solenopsis invicta towards other ants is not affected by colony rafting. Asian Myrmecology 8: 107-110. https:// doi.org/10.20362/am.008007

Hui Y, Li Y, Yang H (2014) Periploca methyl alcohol extraction insect disinfestation active ingredient separation and determination research. Journal of Yanan Univeristy (Natural Science Edition) 33: 42-44.

Jiang C, Wang K, Zhang H, Zhou S (2010) Study on the insect diversity in the occurrence area of Solenopsis invicta. Journal of Anhui Agriculture Science 38: 13225-13228.

Jiang S, Huang S, Chen X, Liu J, Yue D (2011) Natural dynamics of Solenopsis invicta Buren in Shenzhen City. Journal of Huazhong Agricultural University 30: 318-321. 
Korzukhin MD, Porter SD, Thompson LC, Wiley S (2001) Modeling temperature-dependent range limits for the fire ant Solenopsis invicta (Hymenoptera: Formicidae) in the United States. Environmental Entomology 30: 645-655. https://doi.org/10.1603/0046225X-30.4.645

Lard C, Willis DB, Salin V, Robison S (2002) Economic assessments of fire ant on Texas urban and agricultural sectors. Southwestern Entomologist 25: 123-137.

Lei Y, Zhou Y, Lu L, He Y (2019) Rhythms in foraging behavior and expression patterns of the foraging gene in Solenopsis invicta (Hymenoptera: Formicidae) in relation to photoperiod. Journal of Economic Entomology 112: 2923-2930. https://doi.org/10.1093/jee/toz175

Li J, Guo Q, Lin M, Jiang L, Ye J, Chen D, Li Z, Dai J, Han S (2016) Evaluation of a new entomopathogenic strain of Beauveria bassiana and a new field delivery method against Solenopsis invicta. PLoS One 11: e0158325. https://doi.org/10.1371/journal.pone.0158325

Li J, Jiang L, Zhang Y, Guo Q, Han S (2018) Study of a new biological control method combining an enteropathogen and a chemical insecticide against Solenopsis invicta (Hymenoptera: Formicidae). Journal of Economic Entomology 111: 817-822. https://doi. org/10.1093/jee/toy028

Li ND, Zeng L, Liang GW, Lu YY (2008) Dynamics of red imported fire ant Solenopsis invicta in Wuchuan, Guangdong. Chinese Bulletin of Entomology 45: 54-57.

Li S, Zeng L, Xu Y, Lu Y (2014) Infestation of red imported fire ants (Solenopsis invicta) at turf plantations and lawns in Guangdong. Journal of Biosafety 23: 103-106.

Li SZ, Jin XX, Chen J (2012) Effects of piperidine and piperideine alkaloids from the venom of red imported fire ants, Solenopsis invicta Buren, on Pythium ultimum Trow growth in vitro and the application of piperideine alkaloids to control cucumber damping-off in the greenhouse. Pest Management Science 68: 1546-1552. https://doi.org/10.1002/ps.3337

Li SZ, Jin XX, Chen J, Lu SE (2013) Inhibitory activities of venom alkaloids of red imported fire ant against Clavibacter michiganensis subsp michiganensis in vitro and the application of piperidine alkaloids to manage symptom development of bacterial canker on tomato in the greenhouse. International Journal of Pest Management 59: 150-156. https://doi.org/1 0.1080/09670874.2013.784931

Li W, Liao K, Lin S, Cao Y (2007) Biocontrol and primary utilization of the red fire ant (Solenopsis invicta). Journal of Shijiazhuang University 2007: 63-66.

Li Z, Zhou Q, Zhang S, Wu Y, Lu Y, Huang S, Zeng L (2011) Evaluation of knowledge of urban and township residents on Solenopsis invicta Buren in Shenzhen. Plant Quarantine 25: 86-90.

Lin H, Chi W, Lin C, Tseng Y, Chen W, Kung Y, Lien Y, Chen Y (2011) Fire ant-detecting canines: a complementary method in detecting red imported fire ants. Journal of Economic Entomology 104: 225-231. https://doi.org/10.1603/ec10298

Liu HW, Lu YY, Wang WK, Chen L (2017) Whole body solvent soak gives representative venom alkaloid profile from Solenopsis invicta (Hymenoptera: Formicidae) workers. Florida Entomologist 100: 522-527. https://doi.org/10.1653/024.100.0305

Liu J, Lu LH, Chen HY, Feng X, Zhou XM, He YR (2006) Red imported fire ant control with fipronil mound drenches and its impact in ant community. Guangdong Agricultural Sciences 5: 24-27. 
Liu X, Lu L, He Y (2010) Isolation and identification of entomopathogenic fungi naturally infecting Solenopsis invicta and their virulence to S. invicta. Chinese Journal of Biological Control 26: 373-376.

Lofgren CS, Williams DF (1982) AvermectinB1a: highly potent inhibitor of reproduction by queens of the red imported fire ant (Hymenoptera: Formicidae). Journal of Economic Entomology 75: 798-803. https://doi.org/10.1093/jee/75.5.798

Lu Y, Wu B, Xu Y, Zeng L (2012a) Effects of red imported fire ants (Solenopsis invicta) on the species structure of ant communities in South China. Sociobiology 59: 275-285. https:// doi.org/10.13102/sociobiology.v59i1.683

Lu Y, Wu BQ, Zeng L, Xu YJ (2012b) Comparison of foraging ability between Solenopsis invicta and Tapinoma melanocephalum (Hymenoptera: Formicidae). Sociobiology 59: 1015-1024.

Lu Y, Liang G, Zeng L (2008) Study on expansion pattern of red imported fire ant, Solenopsis invicta Buren, in South China Scientia Agricultura Sinica 41: 1053-1063.

Lu Y, Zeng L (2015) 10 years after red imported fire ant found to invade China: history, current situation and trend of its infestation. Plant Quarantine 29: 1-6.

Lu YY (2014) Long-distance spreading speed and trend predication of red imported fire ant, Solenopsis invicta Buren, in mainland China. Guangdong Agricultural Sciences 10: 70-72.

Luo ZD (2005) Harm of red imported fire ants to power facilities and their control. Guangdong Electric Power 18: 1-3.

Lyu DP, Lee HS (2017) The red imported fire ant, Solenopsis invicta Buren (Hymenoptera: Formicidae: Myrmicinae) discovered in Busan sea port, Korea. Korean Journal of Applied Entomology 56: 437-438. https://doi.org/10.5656/ksae.2017.11.0.049

Ma J, Hu X, Wu J, Zhao J, Chen N (2010) An analysis for the interception dynamic of Solenopsis invicta Buren at ports in Guangdong. Journal of Environmental Entomology 32: 122-124.

Miao J, Ma F, Zeng X (2009) Susceptibility to phoxim and acetyl cholinesterase activity of the red imported fire ant (Solenopsis invicta Buren). Chinese Agricultural Science Bulletin 25: 200-202.

Ministry of Agriculture and Rural Affairs of the People's Republic of China (2013) Guidelines for chemical prevention and control of Solenopsis invicta Buren. Ministry of Agriculture and Rural Affairs (Beijing): 1-5.

Ministry of Agriculture and Rural Affairs of the People's Republic of China (2018) List of administrative areas infected by agricultural plant quarantine pests, china and list of agricultural plant quarantine pests occurred in China in year of 2018. http://www.moa.gov.cn/ govpublic/ZZYGLS/201806/t20180625_6153138.htm [Accessed on: 2018-6-29]

Moloney S, Vanderwoude C (2010) Red imported fire ants: a threat to eastern Australia's wildlife? Ecological Management \& Restoration 3: 167-175. https://doi. org/10.1046/j.1442-8903.2002.t01-1-00109.x

Morrison JJE, Williams DF, Oi DH, Potter KN (1997) Damage to dry crop seed by red imported fire ant (Hymenoptera: Formicidae). Journal of Economic Entomology 90: 218222. https://doi.org/10.1093/jee/90.1.218

Obin MS, Vander Meer RK (1985) Gaster fagging by fire ants (Solenopsis spp.): functional significane of venom disperal behavior. Journal of Chemical Ecology 11: 1757-1768. https:// doi.org/10.1007/BF01012125 
Pan F (2017) Study on toxicity on several insecticides and controlling efficiency of bait against Solenopsis invicta Buren. South China Agricultural University (Guangzhou): 2-3.

Pan F, Lu Y, Wang L (2017) Toxicity and sublethal effects of sulfoxaflor on the red imported fire ant, Solenopsis invicta. Ecotoxicology and Environmental Safety 139: 377-383. https://doi. org/10.1016/j.ecoenv.2017.02.014

Pan Y (2013) Damage of Solenopsis invicta on dykes and dams and its management. Guangdong Water Resouces and Hydropower 9: 1-17.

Pascoe A (2002) Strategies for managing incursions of exotic animals to New Zealand. Micronesica 6: 129-135.

Porter SD, Savignano DA (1990) Invasion of polygyne fire ants decimates native ants and disrupts arthropod community. Ecology 71: 2095-2106. https://doi.org/10.2307/1938623

Qi G, Huang Y, Cen Y, Lv L (2015) Effects of the red imported fire ant, Solenopsis invicta Buren, on the structure and diversity of the ant community in a human disturbed area. Chinese Journal of Applied Entomology 52: 1368-1375.

Qin D, Huang R, Li Z, Wang S, Cheng D, Zhang Z (2018) Volatile component analysis of Michelia alba leaves and their effect on fumigation activity and worker behavior of Solenopsis invicta. Sociobiology 65: 170-176. https://doi.org/10.13102/sociobiology.v65i2.2014

Qin W, Chen X, Hooper-Bui LM, Cai J, Wang L, Sun Z, Wen X, Wang C (2019a) Foodburying behavior in red imported fire ants (Hymenoptera: Formicidae). Peerj 7: e6349. https://doi.org/10.7717/peerj.6349

Qin W, Lin S, Chen X, Chen J, Wang L, Xiong H, Xie Q, Sun Z, Wen X, Wang C (2019b) Food transport of red imported fire ants (Hymenoptera: Formicidae) on vertical surfaces. Scientific Reports 9: 3283. https://doi.org/10.1038/s41598-019-39756-4

Qiu HL, Fox EGP, Qin CS, Zhao DY, Yang H, Xu JZ (2019) Microcapsuled entomopathogenic fungus against fire ants, Solenopsis invicta. Biological Control 134: 141-149. https:// doi.org/10.1016/j.biocontrol.2019.03.018

Qiu HL, Lu LH, Zhang CY, He YR (2014a) Behaviour of Solenopsis invicta workers to protect pupae from infection by Metarhizium anisopliae. Chinese Journal of Applied Ecology 25: 2658-2664.

Qiu HL, Lu LH, Zhang CY, He YR (2014b) Pathogenicity of individual isolates of entomopathogenic fungi affects feeding preference of red imported fire ants Solenopsis invicta. Biocontrol Science and Technology 24: 1286-1296. https://doi.org/10.1080/09583157. 2014.933313

Qiu HL, Cheng DF (2017) A chemosensory protein gene Si-CSP1 associated with necrophoric behavior in red imported fire ants (Hymenoptera: Formicidae). Journal of Economic Entomology 110: 1284-1290. https://doi.org/10.1093/jee/tox095

Qiu HL, Lu LH, Shi QX, Tu CC, Lin T, He YR (2015) Differential necrophoric behaviour of the ant Solenopsis invicta towards fungalinfected corpses of workers and pupae. Bulletin of Entomological Research 105: 607-614. https://doi.org/10.1017/ S0007485315000528

Qiu HL, Lu LH, Zalucki MP, He YR (2016) Metarhizium anisopliae infection alters feeding and trophallactic behavior in the ant Solenopsis invicta. Journal of Invertebrate Pathology 138: 24-29. https://doi.org/10.1016/j.jip.2016.05.005 
Qiu X, Zhang B, Y. H, Gao Y, Chen T, Lu LH (2014c) Dietary preference and polymorphism of Solenopsis invicta foragers in China in summer and autumn. Journal of South China Agricultural University 35: 63-66.

Ross KG, Keller L (2003) Ecology and evolution of social organization: insights from fire ants and other highly eusocial insects. Annual Review of Ecology \& Systematics 26: 631-656. https://doi.org/10.1146/annurev.es.26.110195.003215

Shao JG, Luo LZ, Chen HT, Jiang XF, Lei CL (2008) Social forms of Solenopsis invicta in China, as identified by multiplex PCR of Gp-9 alleles. Acta Entomologica Sinica 51: 551-555.

Song Z, Lu Y, Xu Y, Huang J, Liang GW, Zeng L (2010) Dynamic of native ants on the lawn with the invasion of Solenopsis invicta Buren. Acta Ecologica Sinica 30: 1287-1295.

Tsai YH, Yang CC, Lin CC, Shih CJ (2009) The impact of the red imported fire ant, Solenopsis invicta, and bait treatment on the diversity of native ants-a case study at National Taipei University, Sanshia campus. Formosan Entomologist 29: 263-277.

Ujiyama S, Tsuji K (2018) Controlling invasive ant species: a theoretical strategy for efficient monitoring in the early stage of invasion. Scientific Reports 8: 9. https://doi.org/10.1038/ s41598-018-26406-4

Vander Meer RK, Pereira RM, Porter SD, Valles SM, Oi DH (2007) Area-wide suppression of invasive fire ant Solenopsis spp. populations. In: Vreysen MJB, Robinson AS, Hendrichs J (Eds) Area-Wide Control of Insect Pests. Springer, Dordrecht, 487-496. https://doi. org/10.1007/978-1-4020-6059-5_45

Vinson SB (1997) Invasion of the red imported fire ant (hymenoptera: Formicidae) spread, biology, and impact. American Entomologist 43: 23-39. https://doi.org/10.1093/ae/43.1.23

Vinson SB (2012) Impact of the invasion of the imported fire ant. Insect Science 20: 439-455. https://doi.org/10.1111/j.1744-7917.2012.01572.x

Vogt JT (2004a) Detection of imported fire ant (Hymenoptera : Formicidae) mounds with satellite imagery. Environmental Entomology 33: 1718-1721. https://doi.org/10.1603/0046$225 x-33.6 .1718$

Vogt JT (2004b) Quantifying imported fire ant (Hymenoptera : Formicidae) mounds with airborne digital imagery. Environmental Entomology 33: 1045-1051. https://doi. org/10.1603/0046-225x-33.4.1045

Vogt JT, Smith WA, Grantham RA, Wright RE (2003) Effects of temperature and season on foraging activity of red imported fire ants (Hymenoptera: Formicidae) in Oklahoma. Environmental Entomology 32: 447-451. https://doi.org/10.1603/0046-225X-32.3.447

Wang C, Chen X, Strecker R, Henderson G, Wen X, Hooper-Bui LM (2016) Individual and cooperative food transport of the red imported fire ant (Hymenoptera: Formicidae): laboratory observations. Journal of Insect Behavior 29: 99-107. https://doi.org/10.1007/ s10905-016-9546-4

Wang C, Chen X, Hooper-Bui LM, Strecker R, Wen YZ, Qin W-Q, Ma T, Sun ZH, Chen XY, Wen XJ (2018a) How do groups of red imported fire ants (Hymenoptera: Formicidae) feed on a droplet of sugar water? Insect Science 25: 499-507. https://doi.org/10.1111/17447917.12435

Wang C, Li S, Lu Y (2014) Discussion of management strategy and method for red imported fire ant based on cognitive level assessment. Guangdong Agricultural Sciences 10: 232-236. 
Wang H, Wang H, Tao Z, Ge Q (2018b) Potential range expansion of the red imported fire ant (Solenopsis invicta) in China under climate change. Journal of Geographical Sciences 28: $1965-1974$.

Wang J, Zhang H, Zeng L, Xu Y (2012) Repellent effects of five plant essential oils on the red imported fire ant, Solenopsis invicta. Sociobiology 59: 695-702.

Wang L (2010) Study on the regularity of movement and activity of red imported fire ant colonies. South China Agricultural University (Guangzhou): 3-6.

Wang L, Chen J (2015) Fatty amines from little black ants, Monomorium minimum, and their biological activities against red imported fire ants, Solenopsis invicta. Journal of Chemical Ecology 41: 708-715. https://doi.org/10.1007/s10886-015-0609-3

Wang L, Elliott B, Jin X, Zeng L, Chen J (2015) Antimicrobial properties of nest volatiles in red imported fire ants, Solenopsis invicta (hymenoptera: formicidae). The Science of Nature 102: 66. https://doi.org/10.1007/s00114-015-1316-1

Wang L, Li S, Wang L, Zeng L, Lu Y (2011) Quarantine treatment of eleven insecticides against the red imported fire ant in turf. Plant Quarantine 25: 13-16.

Wang L, Lu Y, Xu YJ, Zeng L (2016) Compatibility of Metarhizium spp. with eight pesticides used in the control of Solenopsis invicta. Chinese Journal of Biological Control 32: 172-179.

Wang L, Xu Y, Li ZL, Zeng L, Lu YY (2018c) Pathogenicity of three strains of Metarhizium anisopliae (Metchnikoff) to red imported fire ant Solenopsis invicta Buren Journal of Environmental Entomology 40: 820-824.

Wang L, Xu YJ, Zeng L, Lu YY (2019) Impact of the red imported fire ant Solenopsis invicta Buren on biodiversity in South China: A review. Journal of Integrative Agriculture 18: 788-796. https://doi.org/10.1016/S2095-3119(18)62014-3

Wang YY, Zong FL (2006) Primary exploreation on registration management of fire ant pesticides in China. Pesticide Science and Administration 27: 39-41.

Wen YZ, Ma T, Chen X, Liu ZT, Zhu CQ, Zhang YY, Strecker R, Henderson G, Hooper-Bui LM, Chen XY, Sun ZH, Wen XJ, Wang C (2016) Essential balm: a strong repellent against foraging and defending red imported fire ants (Hymenoptera: Formicidae). Journal of Economic Entomology 109: 1827-1833. https://doi.org/10.1093/jee/tow130

Wetterer JK (2013) Exotic spread of Solenopsis invicta Buren (Hymenoptera: Formicidae) beyond North America. Sociobiology 60: 53-63. https://doi.org/10.13102/sociobiology. v60i1.50-55

Williams DF, Oi DH, Porter SD, Pereira RM, Briano JA (2003) Biological control of imported fire ants (Hymenoptera: Formicidae). American Entomologist 49: 150-163. https://doi. org/10.1093/ae/49.3.150

Wojcik DP, Allen CR, J. BR, Forys EA, Jouvenaz DP, Lutz RS (2001) Red imported fire ants: impact on biodiversity. American Entomologist 47: 16-23. https://doi.org/10.1093/ ae/47.1.16

Wu B, Lu Y, Zeng L, Huang H (2009) Influence of red imported fire ant on ant community in different distances around separate mound. Scientia Agricultura Sinica 42: 4248-4259.

Wu B, Lu Y, Liang GW, Zeng L (2010) Influence of the red imported fire ant, Solenopsis invicta Buren (Hymenoptera: Formicidae) on the diversity of ant communities in a newly infested longan orchard and grass areas nearby. Acta Ecologica Sinica 30: 2075-2083. 
Wu B, Lu Y, Zeng L, Liang GW (2008) Influences of Solenopsis invicta Buren invasion on the native ant communities in different habitats in Guangdong. Chinese Journal of Applied Ecology 19: 151-156.

Wu B, Wang L, Liang G, Lu Y, Zeng L (2014a) Food competition mechanism between Solenopsis invicta Buren and Tapinoma melanocephalum Fabricus. Sociobiology 61: 265-273. https://doi.org/10.13102/sociobiology.v61i3.265-273

Wu D, Zeng L, Lu Y, Xu Y (2014b) Effects of Solenopsis invicta (Hymenoptera: Formicidae) and its interaction with aphids on the seed productions of mungbean and rapeseed plants. Journal of Economic Entomology 107: 1758-1764. https://doi.org/10.1603/ ec14162

Wu WB, Hong TS, Zeng L, Xu YJ, Huang DL, Chileshe JM, Chen JT, Yi CD, Liu XY, Lu DH (2014c) Detection of Solenopsis invicta (Hymenoptera: Formicidae) nests using spectral data. Florida Entomologist 97: 967-971. https://doi.org/10.1653/024.097.0354

Xi Y, Lu Y, Liang GW, Zeng L, Xu Y (2010a) Effects of the red imported fire ant (RIFA), Solenopsis invicta Buren, on diversity and stability of invertebrate community in litchi orchards. Acta Ecologica Sinica 30: 2084-2099.

Xi Y, Lu YY, Zeng L, Liang GW (2010b) Influence of Solenopsis invicta Buren on the physical and chemical properties of soils in litchi orchards. Journal of Environmental Entomology 32: $145-151$.

Xian X, Zhou P, Wan F, Zhang G (2019) The analysis of interception of red imported fire ant (Solenopsis invicta Buren) from China's entry ports. Plant Quarantine 33: 41-45.

Xiong T, Qiu X, Ling S, Liu J, Zeng X (2019) Interaction of fipronil and the red imported fire ant (Solenopsis invicta): Toxicity differences and detoxification responses. Journal of Insect Physiology 115: 20-26. https://doi.org/10.1016/j.jinsphys.2019.03.001

Xu M, Lu Z, Lu YY, Balusu RR, Ajayi OS, Fadamiro HY, Appel AG, Chen L (2018a) Cuticular hydrocarbon chemistry, an important factor shaping the current distribution pattern of the imported fire ants in the USA. Journal of Insect Physiology 110: 34-43. https://doi. org/10.1016/j.jinsphys.2018.08.006

Xu Q, Li J, Ren S (2013) Selection of Metarhizium flavoviride isolates to control the red imported fire ant Solenopsis invicta Chinese Journal of Biological Control 29: 384-388.

Xu Y, Huang J, Lu Y, Zeng L, Liang G (2009a) Observation of nuptial flights of the red imported fire ant, Solenopsis invicta (Hymenoptera: Formicidae) in mainland China. Sociobiology 54: 831-840.

Xu Y, Huang J, Zhou A, Zeng L (2012) Prevalence of Solenopsis invicta (Hymenoptera: Formicidae) venom allergic reaction in mainland China. Florida Entomologist 95: 961-965. https://doi.org/10.1653/024.095.0421

Xu Y, Lu Y, Huang J, Zeng L, Liang G (2009b) Cold hardiness of natural populations of the red imported fire ant, Solenopsis invicta Buren (Hymenoptera: Formicidae) in Shenzhen, Guangdong. Acta Entomologica Sinica 52: 974-983.

Xu Y, Lu Y, Pan Z, Zeng L, Liang G (2009c) Heat tolerance of the red imported fire ant, Solenopsis invicta (Hymenoptera: Formicidae) in mainland China. Sociobiology 54: 115-126.

Xu Y, Lu Y, Zeng L (2009d) Colony structure and dynamic of the fire ant Solenopsis invicta Buren in several habitats. Acta Phytophylacica Sinica 36: 575-576. 
Xu Y, Zeng L, Lu Y, Liang GW (2009e) Food content of refuse piles of the red imported fire ant, Solenopsis invicta Buren (Hymenoptera: Formicidae). Acta Ecologica Sinica 29: 5791-5798.

Xu YJ, Zeng L, Lu YY, Liang GW (2009f) Effect of soil humidity on the survival of Solenopsis invicta Buren workers. Insectes Sociaux 56: 367-373. https://doi.org/10.1007/s00040009-0032-2

Xu YQ, Chen L, Wang WK (2018b) Influence of fatty acids on the necrophoric behavior of the red imported fire ant, Solenopsis invicta (Hymenoptera: Formicidae) Acta Entomologica Sinica 61: 1414-1420.

Yan Q, Zeng X, Miao J (2011) Insecticide sensitivity and metabolic enzyme activity of the larvae of the red imported fire ant (Solenopsis invicta Buren) Chinese Agricultural Science Bulletin 27: 293-296.

Yang CC, Ascunce MS, Luo LZ, Shao JG, Shih CJ, Shoemaker D (2012) Propagule pressure and colony social organization are associated with the successful invasion and rapid range expansion of fire ants in China. Molecular Ecology 21: 817-833. https://doi.org/10.1111/ j.1365-294X.2011.05393.x

Yang J, Sun F, Liao K, Wu W, Pang H, Pang Y (2009) Bioassay of 4 strains of Beauveria bassiana against Solenopsis invicta. Journal of Environmental Entomology 31: 46-51.

Yu HY, Liu SH, Zhao N, Li D, Yu YT (2011) Characteristics of air temperature and precipitation in different regions of China from 1951 to 2009. Journal of Meteorology and Environment 27: 1-11.

Yu X, Wang L, LIang G, Zeng L (2015) Population dynamics of a Solenopsis invicta population and associated nontarget arthropod community in a lawn after pesticide application Chinese Journal of Applied Entomology 52: 1353-1360.

Zeng L, Lu Y, He X, Zhang W, Liang G (2005a) Identification of red imported fire ant Solenopsis invicta to invade mainland China and infestation in Wuchuan, Guangdong. Chinese Bulletin of Entomology 42: 144-148.

Zeng L, Lu YY, Chen ZN (2005b) Monitoring and management of red imported fire ant. Guangdong science and Technology Press (Guangzhou): pp. 32-34.

Zhang B, He Y, Chen T, Qi G, Lv L (2015) Dietary composition of foragers of the red imported fire ant, Solenopsis invicta Buren (Hymenoptera: Formicidae) in two habitats, mulberry orchard and barren land, in South China. Acta Entomologica Sinica 58: 382-390.

Zhang B, Kong F, Wang H, Gao X, Zeng X, Shi X (2016a) Insecticide induction of O-demethylase activity and expression of cytochrome $\mathrm{P} 450$ genes in the red imported fire ant (Solenopsis invicta Buren). Journal of Integrative Agriculture 15: 135-144. https://doi. org/10.1016/s2095-3119(15)61072-3

Zhang B, Zhang L, Cui R, Zeng X, Gao X (2016b) Cloning and expression of multiple cytochrome P450 genes: Induction by fipronil in workers of the red imported fire ant (Solenopsis invicta Buren). PLoS One 11: e0150915. https://doi.org/10.1371/journal. pone. 0150915

Zhang H (2008) Research on the insect diversity in the area of red imported fire ant (Solenopsis invicta). Guangxi Normal University (Guilin): 3-4. 
Zhang L, Zhang P, Cao L, Han R (2010) Susceptibility of red imported fire ant queens to the entomopathogenic nematodes Steinernema carpocapsae All and S. scapterisci. Sociobiology 55: 527-546.

Zhang Q, Lin L, Chen H, Chen P, Lu W, Li Y (2006) An investigation on the first human death incident caused by the bite of red imported fire ants. Disease Surveillance 21: 654-656.

Zhang X, Chen S, Li Z, Xu Y (2017a) Effect of sweeteners on the survival of Solenopsis invicta (Hymenoptera: Formicidare). Journal of Economic Entomology 110: 593-597. https:// doi.org/10.1093/jee/tox038

Zhang X, Hou YM (2014) Invasion history of Solenopsis invicta (Hymenoptera: Formicidae) in Fujian, China based on mitochondrial DNA and its implications in development of a control strategy. Insect Science 21: 493-498. https://doi.org/10.1111/17447917.12042

Zhang Y, Fu J, Huang C, Cheng D, Huang R, Zhang Z (2017b) Insecticidal activity of the soil in the rhizosphere of Viburnum odoratissimum against Solenopsis invicta (Hymenoptera: Formicidae). Sociobiology 64: 1-6. https://doi.org/10.13102/sociobiology.v64i1.1067

Zhang Y, Ma JH, JIn GY, Huang JP (2007) Definition and management on key area of Solenopsis invicta control in port. Plant Quarantine 21: 56-57.

Zhao J, Xu YJ (2015) Survey of the prevalence of fire ant sting accidents based on internet reports. Chinese Journal of Applied Entomology 52: 1409-1412.

Zhao J, Zhong PS, Zhang SS, Song XX (2008) Control effect of Solenopsis invicta Buren in transformer substations. Chinese Journal of Hygienic Insecticides \& Equipments: 267-269.

Zhong P, Zhao J, Zhang S, Feng J (2008) Indoor toxic study of several plant extracts on red imported fire ant. Journal of Huizhou University 28: 41-44.

Zhou A (2009) Risk evaluation and teatment technologies of red imported fire ant for export commodities in port. South China Agricultural University (Guangzhou): 2-4.

Zhou A, Liang G, Lu Y, Zeng L, Xu Y (2014) Interspecific competition between the red imported fire ant, Solenopsis invicta Buren and ghost ant, Tapinoma melanocephalum Fabricius for honeydew resources produced by an invasive mealybug, Phenacoccus solenopsis Tinsiley. Arthropod-Plant Interactions 8: 469-474. https://doi.org/10.1007/ s11829-014-9324-1

Zhou A, Lu Y, Zeng L, Xu Y, Liang G (2012a) Does mutualism drive the invasion of two alien species? The case of Solenopsis invicta and Phenacoccus solenopsis. PLoS One 7: e41856. https://doi.org/10.1371/journal.pone.0041856

Zhou A, Lu Y, Zeng L, Xu Y, Liang G, (2012b) Effects of honeydew of Phenacoccus solenopsis on foliar foraging by Solenopsis invicta (Hymenoptera: Formicidae). Sociobiology 59: 71-79. https://doi.org/10.13102/sociobiology.v59i1.668

Zhou A, Lu Y, Zeng L, Xu Y, Liang G (2013) Solenopsis invicta (Hymenoptera: Formicidae), defend Phenacoccus solenopsis (Hemiptera: Pseudococcidae) against its natural enemies. Environmental Entomology 42: 247-252. https://doi.org/10.1603/en12168

Zhou A, Lu YY, Zeng L, Xu YJ, Liang GW (2012c) Effects of honeydew of Phenacoccus solenopsis on foliar foraging by Solenopsis invicta (Hymenoptera: Formicidae). Sociobiology 59: 71-79. https://doi.org/10.13102/sociobiology.v59i1.668 
Zhou A, Zeng L, Lu Y, Xu Y, Liang G (2012d) Fire ants protect mealybugs against their natural enemies by utilizing the leaf shelters constructed by the leaf roller Sylepta derogata. PLoS One 7: e49982. https://doi.org/10.1371/journal.pone.0049982

Zhou AM, Liang GW, Zeng L, Lu YY, Xu YJ (2017) Solenopsis invicta suppress native ant by excluding mutual exploitation from the invasive mealybug, Phenacoccus solenopsis. Pakistan Journal of Zoology 49: 133-141. https://doi.org/10.17582/journal.pjz/2017.49.1.133

Zhou AM, Wu D, Liang GW, Lu YY, Xu YJ (2015) Effects of tending by Solenopsis invicta (Hymenoptera: Formicidae) on the sugar composition and concentration in the honeydew of an invasive mealybug, Phenacoccus solenopsis (Hemiptera: Pseudococcidae). Ethology 121: 492-500. https://doi.org/10.1111/eth.12363

Zhou Y, Lei Y, Lu L, He Y (2019) Temperature- and food-dependent foraging gene expression in foragers of the red imported fire ant Solenopsis invicta Buren (Hymenoptera: Formicidae). Physiological Entomology. https://doi.org/10.1111/phen.12304

Zhou Y, Lu Y, Ma Q, Zhang Z (2018) The effects of cyantraniliprole on the behavior and lethality of the worker ants of Solenopsis invicta. Guangdong Agricultural Sciences 45: 75-79. 